\title{
Educate or serve: the paradox of "professional service" and the image of the west in legitimacy battles of post-socialist advertising
}

\author{
Zsuzsanna Vargha
}

Published online: 19 January 2010

(C) The Author(s) 2010. This article is published with open access at Springerlink.com

\begin{abstract}
This article investigates a puzzle in the rapidly evolving profession of advertising in post-socialist Hungary: young professionals who came of age during the shift to market-driven practices want to produce advertising that is uncompromised by clients and consumers, and to educate others about western modernity. It is their older colleagues - trained during customer-hostile socialism-who emphasize that good professionals serve their clients' needs. These unexpected generational positions show that 1) professions are more than groups expanding their jurisdiction. They are fields structured by two conflicting demands: autonomy of expertise and dependence on clients. We can explain the puzzle by noting that actors are positioning themselves on one or the other side based on their trajectory or movement in the field relative to other actors. Old and new groups vie for power in the transforming postsocialist professional field, responding to each other's claims and vulnerabilities, exploiting the professional field's contradictory demands on its actors. 2) The struggle is not between those who are oriented to the west and those that are not. Rather, the west is both the means and the stake of the struggle over historical continuity and professional power. Imposing a definition of the west is almost the same as imposing a definition of the profession on the field. In this historical case, "field" appears less as a stable structure based on actors' equipment with capital, than as dynamic relations moved forward by contestation of the field's relevant capital.
\end{abstract}

\section{Introduction}

"I think the entire profession is at a horrible level, I mean the kind of [advertising] work that is visible in the street! And it is often not the [ad] agency's fault; often it is the client's fault. So, I've seen countless times that we bring a very good proposition, and then the client, let's say, blends together

Z. Vargha $(\square)$

Columbia University, New York, NY, USA

e-mail: zv2003@columbia.edu 
two concepts, or changes the headline, and the entire concept collapses. And we tell him in vain that it doesn't make sense this way-he says, I'm the client, I'm the one who is paying for this, and I want it. And then that's what will get put out. So most of the time the agency, if there is a conflict, will be in a subordinate role and then we are forced to do what the client asks."

"Maybe it's time not to search for the flaw in the client. One must be able to understand the problem of the client, and if the client feels that their problem has been understood, if they feel that you've attuned yourself to that thinking, that strategy...which prevails at that company, then all you have to do is to earn [the client's] professional trust."

These statements are from Hungarian advertising professionals, one young, one older. The first quotation is typical of young professionals who long for creative autonomy and independence from clients, while the second is from their older colleagues who argue for serving the needs of the market. But this coupling of views and people is counterintuitive. Our common sense dictates that older "socialist" professionals are wary of the market because it is an alien form of economic organization for them. Their professional knowledge had been relevant to another context, where advertising had different goals, competition was rare, and client servicing was notoriously undervalued. ${ }^{1}$ On the other hand, the rules of capitalism, such as sustaining a business, are more natural for the younger professionals. The young who were socialized into the market economy should be the ones comfortable with a service role for their profession, while the "old guard" from socialism should be opposing it.

Is this a story about the spread of western models of professionalization? The argument in that case would be that Hungarian advertising had not been a profession, since entry had not been strictly regulated and professional expertise was easily obtained on the job. As advertising forms into a profession, however, it strives for more and more autonomy from economic constraints; thus, younger generations have been increasingly part of the professionalization project. Advertising not being a profession in the socialist period and then becoming one would be responsible for participants' views. The old practitioners lack professional training, and thus they stick to business principles-which are not specific to advertising and are client-oriented-while the young have training, in fact they are already "true" professionals, and so they want autonomy. This account fits with Michael Kennedy's earlier analysis of American advisers' encounters with East European managers. As the latter gain training in business administration, they increasingly speak in the name of a universal, global business culture (which had been first represented by foreign advisers) rather than local culture (Kennedy 2002).

However, both empirical evidence and theoretical perspective refute this story. Empirically, I found that many young practitioners have no professional training - and

\footnotetext{
${ }^{1}$ The socialist advertising practitioners had a history of being "educators." As Faraday and others have observed, cultural producers could easily occupy the intellectual-educator position during socialism (Faraday 2000). Advertising in particular had the role of introducing the new, modern socialist lifestyle and the general achievements of socialism, as well as teaching people how to use new products (Gronow 2003; Abrams 2007).
} 
its associated habitus - since they entered advertising at the end of 1980s and beginning of $1990 \mathrm{~s}$, a period of professional openness. Thus, a lot of the young professionals were not trained in specific advertising expertise, and therefore in a basic sense they are not more professional than their elders. By contrast, the classical elements of organizing a closed professional field had already been present in the socialist period, from the 1970s: professional associations (the Hungarian Advertising Association was established in 1975), Code of Ethics (1970s), organization and participation in international advertising conferences, higher education courses in advertising (see MRSz 2008). At best, what we can establish is that the professional field experienced a window of relative openness in the "transitional period" of the late 1980s and early 1990s.

Theoretically, the object is not to define what a profession is and to compare Hungarian practices to that measure. That would be reasoning backwards. Abbott (1988) has warned against attempts to list the requisite attributes of a profession. In fact, the debate about what constitutes a profession is precisely the object of study here, since that is what is at stake in the debates of advertising. Professionalism is an ideal with which groups define and distinguish themselves. From this perspective, it is irrelevant to parse the degree to which advertising is really a profession. Not to mention that such an exercise would typically look for a profession's attributes that had been identified in the west-where the literature on professions originates. Instead of disregarding the claims of some actors and imposing a normative definition, this research deliberately makes no assumptions about what a profession is, in order to look at how actors struggle to arrive at such a definition themselves.

My argument has two parts. First, we can think of profession not as a group but as a field. Instead of merely a group of actors who share similar expertise (professionals) and who want to expand its jurisdiction, profession is a field that is constructed along contradictory demands on its actors - autonomy and heteronomy (subjection to another field's principles). Professions as fields of expertise are motivated by, and balance, two conflicting claims: autonomy of expertise and dependence on clients. These opposing demands enable and constrain professional contention over status hierarchies. Experts formulate and contest the definition of "professional" relative to each other, taking positions to maximize the power of their expertise. ${ }^{2}$ The side they take depends not only on their nominal positions (creative worker vs. manager) and not even on their individual careers (socialistminded or capitalist-raised). It depends on their trajectory-understood as social origins and advancement in the field relative to other actors-which forms the basis of their positioning strategies.

The second part of my argument concerns the west. Unlike in Kennedy's case, orientation to the west does not distinguish the groups, since all locals reference the west (not just Westerners and westernized locals). Rather, the west is the means and the stake of struggle between generations of professionals. Claims about the west from both sides constitute how the struggle is conducted. Struggling for domination

\footnotetext{
${ }^{2}$ Eyal (2002) pointed out that the sociology of professions has studied groups of experts and not expertise that emerges through discourse. I take a similar approach, putting the emphasis on the relational nature of fields.
} 
of the field, actors contest the very properties of the western (the modern) and develop different "wests" for themselves that support their professional claims. In fact, the capacity to represent the west is almost synonymous with the capacity to impose one's definition of the profession on the field.

The key to the puzzle, then, is that the old and the young professionals are entrenched in different kinds of advertising expertise, and using that expertise they engage in positioning games relative to each other. Social actors are not forming their views based on their direct circumstances. Rather, in Pierre Bourdieu's terms, actors' position-takings are mediated by the continuously shifting structure of positions and position-takings in the professional field where they operate. The maneuvering to maximize the power of their expertise is what prompts young advertising practitioners to be "educators," and the old to be defendants of market conditions. Incumbent older practitioners are invested in local knowledge about advertising, and want to prove the relevance of their non-capitalist expertise. Meanwhile, the young newcomers are experts in western culture and as incoming challengers they fight for its relevance.

The bottom line is that actors' trajectories and their relative positioning together account for the counterintuitive stances of Hungarian advertising professionals. Thus, "education" is not inherently the young generation's mission-it is not inscribed in its career and experience. Based on the latter, the young professionals are predisposed to represent market principles just as well as professional autonomy. So why don't they? Because they enter the already occupied advertising field and articulate their stance against those who are already there-the profession's "elders" - and they are limited in what they can represent in light of that group's claims. The same is true for the older generation, which could have pushed for advertising's need for creative autonomy and its mission to educate, but were limited by the younger group's challenges to their competence in capitalism.

In the following sections I develop this argument. First I introduce a modified concept of professional field that accommodates the contradictory nature of professions. Second, I discuss advertising in this new framework, and find that the existing western literature cannot explain the post-socialist puzzle. I argue that the reason is that their theoretical model only captures current intraorganizational tensions, whereas we have to look beyond these-at trajectories in the broader social and professional field. Thus, in the third section I approach the puzzle from the perspective of the larger social transformation in Eastern Europe, and conclude that generational differences in professional position will be coupled with actors' relationship to the west. I then discuss my research methods and introduce my data, interviews with professionals at advertising agencies in Hungary. Then I trace the young and old group's trajectories, in two steps. First, I describe professionals' typical career paths, and establish the differential expertise of the two generations - as if they existed in isolation from each other. But position (and position-taking) can only be understood in relation to other actors and positions, not simply as the result of biography. Therefore, in the second part I analyze the two generation's views as strategies in the field's positioning game, shaping and shaped by Eastern European large-scale social struggle. To demonstrate the validity of my claims, I present evidence from the interviews with Hungarian advertising professionals. 


\section{A more comprehensive theory of professions: integrating the tension of autonomy and dependence}

By applying a specific reading of Pierre Bourdieu's theory of fields to professions, I am able to clarify how professionals form their views, the core of our puzzle. Our intuitive prediction that young professionals promote markets while old professionals have the mission to educate has been simplistic, since all actors of the field are subject to contradictory expectations that they must balance. In what follows I treat advertising as a profession in the broad sense, that is, as an area of expertise that carves out a space for itself among other professions, and which separates itself from the non-experts.

What is central is that advertising displays the tension between autonomy and dependence. Its practitioners feel the need to engage in educating their clients - and the larger public - into what is modern, yet they also want to serve their clients well. This dynamic is true for all professions, and the case of post-socialist advertising highlights it. The tension between determining the audience's needs versus adapting to the latter's demands is simply more accentuated here than in classical professions. The explicitness of having to cater to clients makes it possible to investigate the central problematic of all professions more closely. ${ }^{3}$

Literature on professions tends to focus too heavily on one of the two conflicting yet inherent aspects of expertise: autonomy from, or dependence on, a clientele. Professions are commonly either depicted as striving for exclusivity of knowledge and monopoly power (Larson 1977; Freidson 1984), or as powerless and subservient to management and bureaucracies (Lash 1990). ${ }^{4}$ The problem with either of these approaches is that servicing clients is not at odds with being a professional. In fact, professions are hybrid entities, indissoluble mixtures of conformity to outside expectations and of obscure realms of knowledge. Clearly, professions need specific expertise that is closed to the public, but they also need a clientele that supports their existence. The latter can manifest itself in many forms, such as an organization or a market.

\footnotetext{
${ }^{3}$ In medicine, an example of tension between the autonomy of professional expertise and dependence on clientele - in the form of organizations such as hospitals, insurance companies, and individual patients - is the current debate in the U.S. about reducing residents' work hours 80 hours per week. At stake are "accountability and professionalism" (Drazen and Epstein 2002: 1272): the safety of the individual patient due to doctor fatigue, and the quality of the professional's training, where longer is thought to be better (Iglehart 2008; Wachter 2008).

4 The main observation about professions has been that they monopolize expertise by building institutions and bodies of knowledge that are inaccessible to the layperson. This focus on a single exclusionary driving force ignores the web of obligations in which professions exist, as well as the enormous efforts required to actually maintain the boundaries of specific expertise and the uncertainty of such a project's success. Others have argued that recently professions have been subdued to more powerful logics than their own - such as bureaucratic organization, management, and public opinion (Evetts 2005). Scholars typically treat this "other logic" as external to how professional status systems work, as one that invades the professional principles. Abbott theorizes clientele but still focuses on the autonomy side of the coin: clients as threat to professional purity (Abbott 1981; Parikh 2001). Abbott and Larson take steps towards the market. Abbott discusses professions as inherently subject to market forces and suggests that certain aspects of professions (such as internal differentiation) arise from to the changing "demand for professional services." But that demand is seen as external to the ecological system of professions, so market remains implicit in the theory. In her work on architecture, Larson acknowledges the integral role of the market imperative as the problem of "heteronomy", or dependence on clients. For example, she notes that "the division of tasks cannot be a division of interests. The brilliant design partner can be allowed to forget the business part of the practice but never to ignore it" (Larson 1993). However, this tension does not form part of the theoretical account.
} 
Pierre Bourdieu's theory of fields captures these contrasting demands on professions by showing that autonomy and dependence are two contradictory principles that structure professions and drive power relations within them. All participants are subject to the contradictory demands, and their side-taking is not at all straightforward (nor is it a strict adherence). But the main point is that professionals try to gain status by taking a side and simultaneously denouncing the opposite side.

By including the contradictory principles in one framework, it becomes clear that there will always be professionals who benefit from defining profession as representing the clientele's interests rather than as exclusive expertise. Actors in a field are engaged in struggles over the rules and the properties of the field because they all want to maximize their power - by imposing their own definition of what the profession is, what kind of expertise matters, and who can enter the profession (Bourdieu 1993). These ideas, in turn, are formulated in terms of the two contradictory principles of autonomy and dependence. Evidently, actors argue for a definition of profession that values their expertise (or in Bourdieu's term, capital). In other words, there is a correspondence between actors' location in the field (the structure of positions) and their views (the structure of position-taking).

\section{Advertising's professional tensions and the Hungarian case}

The literature on new media industries primarily focuses on the tension in actors' current position - occupational or organizational roles - and that is insufficient to explain the generational divide in post-socialist Hungary. ${ }^{5}$ Supporting the notion that current circumstances are responsible for actors' views, studies of advertising organizations in the U.S., the UK and Western Europe suggest that the debate on dependence and independence from the clientele typically structures the advertising field along occupational lines (for a review of research on advertising organizations, see McFall 2004; Cook 2007). Research on advertising organizations in the "west" often emphasize that jobs are nominally distinguished by how client-oriented they are. Therefore we could hypothesize that, more generally, one's task within advertising determines one's position in the field, because it indicates the degree of an actor's dependence on the clientele.

Yet, as the introductory quotations exemplify, the occupational divide hypothesis does not hold in Hungarian advertising. The first complaint about lack of creative autonomy that was presented in the Introduction actually comes from an "account," the Hungarian term for account manager, which is a client service job. It is the second, client-oriented approach that comes from a kreativ ${ }^{6}$ So why doesn't the

\footnotetext{
${ }^{5}$ The focus of this literature has been to understand the place of creativity and collaboration in organizations - - hence it is interested in the myths around creative workers, and the entire organization's work towards the cultural product, which is where questions of cooperation and conflict arise. The other reason is empirical ethnocentrism, which has focused on western cases where divides other than "nominal" occupational ones may not readily be visible or relevant in the studied historical moment.

${ }^{6}$ Account (abbreviated from the English job title of account manager) is the actual job title in Hungarian advertising, most often without translation into Hungarian. It is pronounced with a Hungarian accent. Kreativ is Hungarian for creative, which is the English title of the core job in advertising (see below). Yurchak (2003) observes a similar linguistic practice in Russia, where advertising workers are called ekaunt-menedzhery and kopiraitery (copywriters).
} 
main fault line of the profession run along occupational lines in Hungarian advertising? First I discuss the specific structuring principles of advertising, then describe the conventional representatives of the autonomy-dependence tension, and finally contrast the latter with the Hungarian case.

The specific expertise that advertising claims for itself is twofold: creativity and knowing the modern. ${ }^{7}$ As a field, advertising is caught between the contradictory requirements of the adjacent but more powerful fields of art and business. ${ }^{8}$ These exert influence in the form of the desire for artistic-creative autonomy, versus the pursuit of profit. Advertising appeals to both of these logics, but it is never accepted by either completely (Lears 1987). So it criticizes these adjacent fields. Advertising often refers to the primacy of art and creativity to declare its ignorance of economic considerations. Turning around, advertising then refers to market research and sales figures to argue that cultural capital is worthless without a paying audience. But critique of art and business can only go so far, since advertising depends at once on the market and on the creative product to survive. To strengthen itself, advertising adopts a mission to educate. On top of educating (informing) people about new products, it purports to educate the masses about culture, and the clients about the masses.

What complicates the business dependence is that as a media industry, advertising works with a double clientele: clients who order advertisements, and consumers who are targeted with those advertisements. Thus, the advertising field operates with the basic triad of client, advertising professional, and consumer. ${ }^{9,10}$ Indeed, advertising shares the problem of dual audience, the sponsor or commissioner of the work and the public or the users of the work, identified in other professions such as

\footnotetext{
${ }_{7}$ Within marketing, "creativity" is specifically assigned to advertising — its mission is to deliver the magic, the idea, the concept (historically this has not always been the case, see Fox 1984; Schudson 1984). At the same time, advertising disseminates knowledge about taste, novelties, and about the proper use of consumer products, and proper behavior in general (Featherstone 1991). In fact, ad men in early 20th century U.S. and postwar Western Europe have seen themselves as "apostles of modernity" (Marchand 1985; De Grazia 2005). Reflecting this duality of advertising expertise, sociologists have described advertising practitioners as "cultural producers" (of the creative product) and as "cultural intermediaries" (to the masses).

${ }^{8}$ This tension also determines the "jurisdictional battles" of advertising (Abbott 1988) with other adjacent professions such as marketing, public relations, graphic design and art photography, over specific tasks.

${ }^{9}$ There are auxiliary institutions such as media buying agencies and technical production companies (e.g., filmmaking studios and graphic design studios), and the media organizations themselves, but in agreement with Cronin (Cronin 2003) I argue that the main dynamic of the field is understood through this triadic relationship. While advertising can usefully be seen as the organizational mediation between product and consumer (Hennion et al. 1989), it has a different focus than the problem of clientele.

${ }^{10}$ Advertising's important third audience is itself, but this point has been emphasized by others so I avoid delving into it for the sake of highlighting the previously "externalized" clientele. Similarly to other "creative professions" (Larson 1993), advertising's autonomy, or the aspiration to it, is manifest in selfreferentiality: both in advertisements and in the prominence of peer judgment (Schudson). Internal closure culminates in the creative award competitions such as the Cannes "Golden Lion," the Eastern European "Golden Drum," and the Hungarian "Golden Blade" (Aranypenge). Ironically, the business aspect of advertising cannot be absent even from such internal conferrals of prestige. The Effie Awards (Effie 2007), which have their Hungarian franchise, reward efficient advertising: one that meets the stated marketing goals of the client both in design and in actual performance (measured in product sales after a campaign), and on top of that achieves the best results with a given budget.
} 
(modernist) architecture and engineering (Larson 1993; Guillen 1997). Both audiences present advertising with pressures it must respond to, and with opportunities it can utilize. Autonomy from marketing managers means to negotiate the time and budget expectations, and to defy the aesthetic judgments of the corporate client. Autonomy from consumers is to design without regard for public need, taste, or input.

In maneuvering for autonomy, advertising plays off the two audiences against each other. Advertising can get its way with the client by referring to the needs of the consumer. This is because the consumer becomes a site of contestation between the client and the agency. The client acts as the representative of the consumer vis-à-vis unintelligible creativity, but advertising defends the consumer from the client's profit-oriented rationalizations and from his "cultural insensitivity" by claiming to represent the consumer credibly (Dávila 2001). Moreover, since it is difficult to figure out what kind of advertisements will like, the two sides argue over just how creative an ad should be based on what consumers reportedly prefer. ${ }^{11}$ Ironically, advertising can gain autonomy from consumer taste through the client's power and by exploiting the ambiguity of performance measures. First, the client has final say in whether the consumer is taken into account. Second, the link between advertising campaign and product sales is hard to prove (Tunstall 1964; Schudson 1984). ${ }^{12}$ Advertising takes credit if sales go up, but if sales go down it's time to criticize the technicalities of measuring an ad's effect on buying behavior. This kind of accounting for failure supports whatever advertising produces vis-à-vis consumers.

The advertising field's tension between art and business devolves on different occupations, namely, "creatives" and account managers, as suggested by studies on advertising professionals in the United States and the United Kingdom. Creatives come up with the idea for an ad, while account executives are responsible for communicating with the client and for coordinating the ad production process. Creatives are closest to the "creative/artistic" pole of the professional field, and they are mystified by an industry that considers them unique individuals with a magical talent to know what works (Gitlin 2000; Hesmondhalgh 2002). Unsurprisingly, they are reported to privilege professional autonomy. Account managers support the myth about creatives but also stress their own importance in translating between creatives and clients (they reformulate the client's business "brief" to a more inspirational language), and in managing the impossible manners of creatives towards clients. They also emphasize the collective nature of the production process and the noncreative work necessary for advertising to succeed, and tend to come down on the

\footnotetext{
${ }^{11}$ Market research, which appeals to the scientific instead of the artistic, is the other main tool of advertising to fend off client intervention and achieve autonomy (Schudson 1984; Mazzarella 2003). This area of expertise, however, is less exclusive to advertising than creative work and also isn't predominant in the Hungarian discourse on professionalism (although it is sometimes noted that clients don't care about research results).

${ }^{12}$ This is true for media industries more generally, where gurus try (often in vain) to predict success. The problem is uncertainty over how cultural consumption works, and how "hits" are generated (Gitlin 2000; (Schudson 1984); Salganik et al. 2006). Advertising is even more complicated because there are two steps: viewing an ad and buying a product. There are in fact two products to worry about: the ad itself and the consumer good it advertises.
} 
side of serving the client's needs (Schudson 1984; Mort 1996; Nixon 1996; Thornton 1999; Soar 2000; Moeran 2003). ${ }^{13}$

The process of advertising production in Hungary is nearly identical to that in the US or the UK, or in India for that matter (Grabher 2001; Hogg and Scoggins 2001; Mazzarella 2003). This coercive isomorphism (DiMaggio and Powell 1983) seems to result from the historical development of post-socialist advertising where large established international firms imported their organizational structures and their client relationship structures to a new market. The production of most advertisements in Hungary also follows the global trend in that it is outsourced from the advertiser (the company that wishes to promote its products) to a single interface: the advertising agency. ${ }^{14}$ As organizations, Hungarian agencies are similar to those around the globe. Like everywhere else, the creative and the account management teams are the agency's core in Hungary. ${ }^{15}$

The fact that the Hungarian advertising industry is isomorphic to its global counterparts makes it even more striking that the tension between organizational tasks is not the most prominent divide in the self-evaluation of the profession. We find kreativ's and accounts on either side of the professionalism debate in Hungarian advertising. ${ }^{16}$ In the following, I argue that Eastern Europe's post-socialist struggle produces the generational divide of opinions and structures the field's social and discursive space. ${ }^{17}$

\footnotetext{
${ }^{13}$ In Abbott's terms, this "status hierarchy" is the result of creatives being the representatives of professional purity while account managers meddle in the "human issues" of advertising work (Abbott 1988).

${ }^{14}$ Hungarian advertising agencies can be commissioned to put out a single ad or a full campaign on multiple communications channels, or to manage all advertisements of a brand (e.g., a product, a company) over a long period. They design the ad technically and conceptually based on the advertiser's guidelines and in negotiation with the client; they buy (or sometimes do) market research; they produce the ad with contractors such as film studios; and they deal with media buying agencies (who buy the place to put the ad). In the U.S. and the U.K. media buying and market research are departments within the advertising firm, in Hungary they are outsourced to adjacent industries (media buying was spun off from the ad agency only recently).

${ }^{15}$ Organizational divergence from the U.S.-U.K. agency design, and in agencies serving larger markets, seems to come from the smaller size of Hungarian agencies, which entails less specialization of tasks and less hierarchy. Budget permitting, internationally owned agencies may add positions such as "strategic planner" (creates a brand's strategy) or "traffic" (coordinates the production process), which are more basic jobs in U.S. and U.K. agencies. Note that since the global language of advertising is English, the professional jargon of Hungarian advertising is also English. Job titles (some partially Hungarianized) are kreativ, account (as in account manager), client service director, and art director, pronounced with a Hungarian accent. The design of (international or Hungarian-owned) agency offices is also similar to the U.S. and the U.K., suggesting creativity and playfulness, where creatives often have their own secluded den or entire floor, complete with a foosball table and other distractions (some agencies distinguish themselves as more conservative).

${ }^{16}$ Hungarian advertising professionals meant advertising in a general sense-rather than just graphic ads, for example - often referring to comprehensive campaigns that include various media (although at the time of research online advertising was not mentioned as a basic example). This is related to the fact that the center of the profession and of production is the "full-service" agency. The agency offers all possible services related to advertising as a one-stop-shop for companies seeking to advertise themselves. The advertiser company contracts with the agency, which in turn coordinates the otherwise multi-faceted planning and production process. The conventional distinction runs between ATL and BTL advertising, and full service includes both. ATL (above the line) advertising such as television, print, radio, and internet refers to high-visibility, high production cost, mass media-based methods. Non-full service agencies are more specialized and customarily only offer internet advertising or so-called BTL (below the line) services. The latter means direct advertising aimed at customers at the sales location or over mail.

${ }^{17}$ My use of the concept of generation to describe the clustering of professionals is grounded in actors' own interpretation of what is happening. Younger professionals would explicitly talk in terms of "generation" and "generational change," in positive terms, while elders mention the term less and more critically.
} 


\section{Large-scale social transformation and the significance of the west}

In the Eastern European setting, the question of how professionals form their views is tied up with the question of how post-socialist actors form their views based on their relationship with the west. From a comparative perspective, advertising in the United States and Western Europe did not undergo a similarly substantial makeover, therefore the old-new opposition is less salient there, although not completely absent (Fox 1984; Mort 1996; Mayer 1958; Thornton 1999). Above all, the educational background and career ladder of advertising professionals have been much more constant over the past 50 years than in Eastern Europe.

The transformation of Hungarian advertising during the 1980s-1990s displays all six "facets" of change in the production of culture identified by Peterson and Anand (Peterson and Anand 2004): technological, organizational structure, law and regulation, industry structure, market, and occupational career. By importing the contemporary western business model of advertising, multiple facets of this culture industry were reconfigured. Most importantly, career prospects completely turned on their heads in advertising. In terms of other facets, the technology of production was updated, advertising work was organized into agencies and internally, into kreativ and account departments; the industry structure now featured dominant international agencies and a fringe of Hungarian ad shops; ${ }^{18}$ the market became a knowable, segmented assemblage of "consumers" instead of the "population." In addition, a new law was passed on advertising and new professional associations sprang up besides the existing ones. ${ }^{19}$ As we examine the trajectories of the field's actors, we will see how these changes correspond with the outcomes of positioning in the professional debates of Hungarian advertising.

The generational differences in Hungarian ad professionals' views are related to two processes: the demographic change in the professional population and the simultaneous negotiation of a non-dominant market's relation to a dominant one. The former may reflect, or be induced by, larger societal change and entails a shift in the legitimacy of knowledge. The latter relationship breeds incessant questioning on the part of non-dominant actors of both authenticity and modernity, which are often organized as generational differences. These are not exclusively post-socialist

\footnotetext{
${ }^{18}$ Within internationally-owned advertising agencies, the global division of labor has meant three things: 1) Hungarian branches benefit from global contracts between their parent company and large advertisers (e.g., McCann Erickson and Coca-Cola), in which the two agree that the agency will produce ads for the company worldwide; 2) having to adapt foreign ad films produced elsewhere in the global agency, and 3) tapping into the vast resources of a global knowledge network (e.g., in the form of regional collaboration or learning from previous projects).

19 The four most prominent ones are Magyar Reklámszövetség (Hungarian Advertising Association, MRSz), Magyar Kommunikációs Ügynökségek Szövetsége (Association of Hungarian Communications Agencies, MAKSz), Önszabályozó Reklámtestület (Self-regulating Board of Advertising, ÖRT), and the International Advertising Association's Hungarian branch.
} 
processes (Dávila 2001) but they are certainly constitutive of the transformations in the former Soviet bloc. ${ }^{20}$

Inevitably, the East European context is key to why the profession's debates are not structured along organizational-occupational lines. By shifting the scale of our analysis it is possible to recognize that the opposition of the old and the young identified in advertising is, in fact, part of a more general struggle in Hungary between the old and the new. It is the large-scale social transformation from communism to post-communism that is reflected in the particular cleavages of advertising. The two age groups can be thought of as representatives of the old and the new regime. ${ }^{21}$ Advertising references the larger political struggle that is taking place in Eastern Europe. In that struggle the establishment of relevant knowledges is at stake: while some actors want to demonstrate socialism's continuing relevance, others want to prove that the new capitalist categories are applicable to the postsocialist context. ${ }^{22}$

The tension around generational succession is instantly translated into a debate about the west. In the post-socialist scenario the new is undoubtedly the western. Eastern Europeans themselves have obsessively been looking west in search of models of modernization for at least 200 years. They have defined their identity in relation to that "other" Europe. ${ }^{23}$ The Cold War intensified this fixation on the affluent west, both because of the separation from it, and because simultaneously, diverse formal and informal institutions wove an increasingly tangible political, social, and material network across the Iron Curtain. Finally, since the political transition of the early 1990s, the west has become the catch-all that automatically justifies a wide range of claims related to being modern and professional, on the basis that if it is western it must be better.

\footnotetext{
20 "Ethnic" advertising in the U.S. shows similarities with Hungary (Dávila 2001). Successive generations of professionals are divided over the quality of Hispanic advertising in the United States, and couch their debates in questions of Latino authenticity (who can represent U.S. Latinos better to clients and consumers) and creativity. Like the young Hungarians, the new Latin-American immigrant professionals challenge the incumbent Hispanic ad-makers and claim that Latin American ads are superior to U.S. Hispanic ones. Compared to Hungary there is an additional dynamic due to the three-way relationship of 1) a non-dominant position (Hispanic) operating within 2) a globally dominant market (United States.), and 3) a non-dominant market (Latin America).

${ }^{21}$ Dunn notes a similar "vernacular" dichotomy of socialist-capitalist, used to craft persons at the postsocialist workplace, that is loaded with other oppositions such as backward-modern, age-youth, stasisdynamism, inadaptability-flexibility (Dunn 2004).

${ }^{22}$ To assume that Hungarian advertising has only recently become a profession-a frequent move within the sociological literature on professions - is to take a side in the very debate that is taking place in advertising. As we see below, the young generation argues precisely that advertising is a "young profession," it is new because there was no advertising in socialism. Therefore, they are the representatives of real professional advertising. Meanwhile, the older generation says advertising is not new, it was in fact much higher quality in socialism, and they are the true professionals, coming from the tradition of awardwinning creative work and yet knowing that their job as professionals is to cooperate, respect, and satisfy clients.

${ }^{23}$ The orientalizing work done by "the west," namely the invention of the very category of "east" should not be discounted (Wolff 1994; Todorova 1997). But here we are interested in the self-image of this objectified population, keeping in mind that while the western gaze helps constitute the east, it does not determine its specific constitution completely.
} 
The west is often equated with another catchphrase, Europe, and both are doxa to which all speakers, even dissenters, must relate. Distinct ways of relating have solidified; as Molnár observes, Hungarians have developed "society-wide interpretive schemes for tackling [foreign] encounters" (Molnár 2005). Advertising professionals mobilize these competing schemes to understand their location in global cultural production. One of the typical models for relating to the west is to identify with it and to accept the universal scale of development. The speaker stands above and outside Hungarian society - thereby extracting herself from responsibility - and criticizes it for its undeveloped state, asserting the need for educating the public to transform. In current Hungarian political discourse this position has been associated with liberal or socialist modernization programs (Melegh 2003).

In their work of mediating culture back and forth between global and local, advertising professionals must delicately balance their distance from the west. Namely, the advertising industry forges national or ethnic identities through its work of creating new markets (Dávila 2001; Mazzarella 2003), and provides the public with cultural tools to define their national identity, while also reflecting the public articulations of that national identity. Thus, it must credibly represent both the Hungarian and the western-modern - to agencies' international headquarters, to clients, and to consumers. Professionals juggle with this tension as they take sides in the autonomy-dependence debate.

Due to the substantial transformation of the social space in Eastern Europe, the conventional structure of the advertising field according to occupational tasks is overshadowed by the split between generations. That divide, between the old socialist and the new western, can be understood as reflective of the schism in the political field, one that large-scale social change necessarily entails. Advertising, then, is yet another domain where the tensions of local-socialist and global-western are played out. The west is inextricably present in the post-socialist professional struggle, and must be taken into account to understand the observed structuring of relations.

While the mutual effects of westernization and expertise in post-socialism have been taken up by others in a similar vein, approaching the question from the analytical perspective of professional field contributes to this body of work. It gives a more complete theory of the origin of different actors' "claims to competence." Earlier studies have tended to assume that the west is a unified notion for postsocialist actors. ${ }^{24}$ The general approach has been to study the heterogeneous category of "managers" in post-socialism, asking whether they resist or adopt the language of universal neoliberal capitalism that is flowing from the west (Kennedy 2002; Weiner 2007; Yurchak 2003). To be sure, attention has been paid to gender and to a single generation - "the last Soviet generation" for Yurchak, or the generation of the transition for Weiner and Stoilkova (2004)-but not in relation to other groups, other generations.

\footnotetext{
${ }^{24}$ The concept of "transition culture" entails that foreigners ultimately have the capacity to define what the west is, and locals either buy into it or resist by emphasizing that global expertise does not help in local post-socialist context.
} 
I analyze the west differently, in three ways. First, the west is the means of struggle, taking place between actors within a concrete professional field. The field approach allows us to see actors in the relations in which they are enmeshed, and to which they respond in their claims about competence and the west. Second, the problem in our case is conflict among local experts over the virtues of the west, where the question is which local experts become "westernized" and why - this has not been taken up in a central way in previous work. ${ }^{25}$

Last but not least, actors contest the very properties of the west (the modern), as the means of struggle for domination of the field: is the west about the market or is it about the "profession;" and is the west different from the national, the eastern, and ultimately, the socialist way of doing? To determine what practices and which professionals represent continuity with socialism, the actors must figure out what in western advertising is different and what is the same as in socialist advertising. Both groups look to the west, the difference is what they see. The young "transitionals" manufacture a particular west for themselves that is the site of professional autonomy. The older generation points out that the west, if anything, is rather the site of modern business practices, which do not allow for the great professionalartistic autonomy that the young seek.

The struggle between socialist continuity and discontinuity does not fully explain why the young are educators. Young Hungarian advertising workers make contradictory claims. They criticize the socialist-trained elders of their profession for not having the spirit of capitalism instilled in them. ${ }^{26}$ Yet as young professionals they want to break away from the constraints of the market imposed on them by clients and consumers. Ironically, it is the socialist older professionals who have to remind the young generation what the principles of capitalist business are.

If the explanation of the puzzle was merely that the "transitional generation" is interested in discontinuity, then why don't they stress their stronger business acumen, their better understanding of market principles, the mission of a capitalist firm to make profit and serve consumers? The answer is they cannot do that because the elders are already saying this, positioned at the top of advertising agencies. By the same token, if the elders were interested in preserving continuity with socialism, they could have emphasized their "mission to educate." But they cannot really do that. With their trajectory, emphasis on educating the public and not devoting themselves to clients would seem too communist. The elders know that this is too much continuity that would made them vulnerable to attacks from newcomers that they are not capitalist enough.

\footnotetext{
${ }^{25}$ Kennedy's case provided a ready distinction between local East Europeans and western foreigners, hence there the insider-outsider tension explained an actor's location in a field organized along the east-west tension. In the present case the east-west division cannot explain everything. The field of advertising is not only organized by the east-west tension but also along generational tensions and professional tensions, all of which become coupled into two poles. The theoretical difference is partly a result of timing: whereas Kennedy contrasted the views of expat managers working in Eastern Europe with the views of locals, in Hungarian advertising after 2000 expat managers are mostly gone - they are an absent referent in a dispute that takes place among different groups of locals. In Kennedy's analysis, the outsider foreigners - and by extension their local converts ("westernized locals")-value discontinuity with socialism and stigmatize the insider locals as representatives of continuity.

${ }^{26}$ As I discuss below, the young professionals say that although the old "masters" had worked in the profession for decades, it doesn't amount to much because advertising did not really have a function in socialism. By function they mean promoting goods to compete with rivals.
} 
In this way, the East European post-socialist historical moment throws into high relief the tension of capitalist professions. As the new and old actors negotiate the meaning of capitalism and their legitimate position in the envisioned new economic system, they wrestle with the demands of specific expertise and the market. What they pick from the west and capitalism depends in part on their own affinities and expertise, but also on the other group's strategy. I explain this in the next section.

\section{Trajectories and relations of the field: how social origin and positioning impact views}

The seemingly "obvious" occupational tension that should dominate post-socialist advertising is not only unsupported empirically, as we have seen, but it is suspect from a theoretical perspective. Pierre Bourdieu warns that actors occupying similar nominal positions may actually have different habitus, and may be differentially equipped with forms of capital relevant in the field, as a result of their past social positions (Bourdieu 1984, 1993). Not only that, but the eventual positions actors can take based on their capital-expertise also depends on the current space of possible positions that can be taken, which is inherited from the previous states of the field (and also shaped by actors themselves). These differences together account for the diverging strategies and views of people who otherwise "look" nominally the same (Bourdieu 1993: 183). Therefore, to predict actors' views we need to look behind a professional's current job title (whether she is a kreativ or an account) and trace their trajectory.

By trajectory Bourdieu means an actor's social origin and his or her movement across social space. The latter comprises the actor's entry into the professional field and the positions occupied by her over time, throughout the successive configurations of the field. This way we have an idea about how that actor got to her observed current position, and what kind of expertise she has amassed during that journey. Empirically trajectory can be approximated by educational background and career. Yet current occupation, biography, and the ensuing expertise-capital do not determine one's views directly.

Trajectory in Bourdieu's sense cannot be understood in isolation, as biography or "career" in stratification research, independent from other actors' biographies. Trajectories are related to other positions in the field, being shaped as other trajectories are also forming. As is shown later, the young group's trajectory is that they enter an already occupied field and position themselves relative to the elders. Thus, the final factor that shapes actors' position-taking is the system of relations in the field at any given moment-how actors are positioned relative to each other. ${ }^{27}$ Views are also formed in relation to one another-they depend on what other points are already occupied by others in the discursive space. The actors' views are in turn associated with their respective trajectories. In the following I present my research methods, then I discuss the typical generational career routes first separately from each other, then exploring their inter-relations in the development of the Hungarian advertising field. Finally, I show how the generations' trajectories and positioning result in the strategies of education and service that have emerged in response to one another.

\footnotetext{
${ }^{27}$ Actors' position-takings (or views) tend to correspond to their respective positions in the field. Note that for Bourdieu, position refers to a complicated understanding of an actor's place relative to other actors, different than "job position" in the advertising organization.
} 


\section{Research methods}

The instrument for exploring the views and background of Hungarian advertising professionals for this study was interviewing. Between 2002 and 2004 a total of 61 intensive interviews were conducted: 56 with advertising professionals working at full-service advertising agencies in Budapest, and an additional five with others who participate in advertising's discourse and who represent bodies that are integral to the profession - three leaders of the main professional organizations and two editors of Kreativ, Hungarian advertising's trade journal. ${ }^{28}$

The contention between old and young professionals suggests that age is the main independent variable to predict ad professionals' views. The age of respondents ranged from 23 to 56, as of 2004. Since the study did not assume that differences in opinion were only associated with age, the sampling aimed to address other variables of theoretical interest: occupation, rank, and ownership of agency. For all age groups, approximately the same number of interviewees was included from both account management and kreativ departments (the main occupations in advertising). The sample contained workers from all organizational levels: 14 CEOs or managing directors, 24 members of top management and middle management, and 18 nonmanagers. Since the Hungarian market is dominated by international agencies $(80 \%$ of revenues), a larger proportion of respondents (36 out of 56) were chosen from there. Interviewees represented 18 agencies from the total of 55 full-service agencies operating in Hungary (2004). Respondents had worked at 11 international agencies out of 18 in total on the market, and at 7 well-known Hungarian-owned agencies out of 37 total. $^{29}$ Even so, Hungarian-owned agencies were over-represented in the sample for purposes of generalization. The sample contained 27 females and 34 males.

The interviews lasted one hour on average and featured both biographical questions about education and advertising career, and general questions about various aspects of the Hungarian advertising profession, such as "What are Hungarian advertisements like?" and "What makes good advertising?" If respondents needed clarification on these questions, they were asked to assess these issues relative to the situation "elsewhere." Pilot interviews showed that respondents frame Hungarian advertising in a western perspective, so the choice of such ambiguous terms served to avoid any explicit reference to the west on the part of the interviewer. Yet they invariably triggered responses that meant "the west," either explicitly (nyugaton, nyugati) or implicitly. Even general phrases such as "abroad" (külföldön), "out there" (kint) and "foreigners" (külföldiek) have the connotation of the west in Hungarian common parlance and they were used in this sense in the interviews. Specific locations such as London or New York were mentioned as models to be followed and thus are interpreted as referring to the west.

\footnotetext{
${ }^{28}$ Three respondents were "foreigners," all trained in Europe, now working in creative or account management positions at international agencies in Hungary. They are local representatives and authentic experts of the west for Hungarians, so their assessment of Hungarian advertising matters because it reinforces Hungarians' beliefs about the west. Their view of Hungary is imbued with ideas about development. They usually see Hungary as inferior to the west and to ad centers in the Middle East or Latin America.

${ }^{29}$ Such a large number of agencies accounts for only $20 \%$ market share.
} 
Based on existing literature on advertising, sampling had focused primarily on occupation and organizational position. After analyzing the data it became clear that generational divisions trumped the other dimensions, while the sample had only included five respondents who were identified as belonging to the older generation. Therefore the interview data from these respondents were complemented with material from the archives of Kreativ, the trade journal of Hungarian advertising to confirm the socialist generation's biography and professional identification. ${ }^{30}$ Comparable information was available on five additional professionals, which brings the total number of "elders" analyzed to 10. Biographical data were collected from the journal's interviews with, and reports on, the "elders" of the profession. Personal views on the profession were assessed from interviews with the "elders" and from opinion pieces written by them. The data so gathered support the findings from my interviews.

\section{The young "educators" and the service-friendly "elders": professional stance as outcome of trajectories and positioning in the post-socialist field}

\section{Populating the field: two trajectories into advertising}

To determine their equipment with expertise, I analyzed the biographies of Hungarian advertising professionals, looking for similarities and differences in educational background and career paths. According to their age, professional career, as well as experience in socialism and knowledge of the west, two main groups emerged: the "elders" and the younger "transitional generation." The small group of older entrants versus the large but distinctively younger group signals the "regime change" in Eastern Europe. ${ }^{31,32}$

\footnotetext{
${ }^{30}$ Kreativ is the magazine read by virtually everyone claiming to be in advertising in Hungary. It is specifically devoted to advertising, not only to marketing generally. Kreativ occupies an important place in Hungarian advertising, and it is intended for and read by professional peers. Therefore it suits the research purpose of examining professional discourse. Moreover, a scan of articles about or by my interview respondents suggests that they take up the views they expressed towards the sociologist also towards their insider public - I did not find significant mismatch between "privately confessed" and "publicly preached" opinion. Kreativ is not only a monthly periodical but also a large news and database portal (www.kreativ. hu) with a subscription-based section and an electronic newsletter.

${ }^{31}$ Not only biological age counts in determining who belongs to which group. Age is important because it speaks about one's life experience: to what extent it pertains to the socialist era. But the date of entry into advertising is just as important, since this gives us a professional's position as incumbent or challenger in the field of expertise, defending the old or promoting the new. In this sense, it matters less that some of the transitional entrants are close to the age of the elders, since their professional experience was gained in the newly shaping field.

${ }^{32}$ The age gap between the two groups cannot be explained away by the sampling method. Of course, there are people between 40 and 50 working in advertising that were not captured by the sample. Anecdotally we know from the older respondents that many of the missing people went into media buying and other adjacent industries. Our expectation based on the older respondents, however, is that the people of this age are located at top positions in significant ad agencies, and this does not seem to be the case. Probes on the background of CEOs and the top account and creative directors in major international and several well-known Hungarian agencies that were not in the sample (obtained from the annual issue of the Great Creative Book (2004) that lists all ad agencies operating in Hungary, and available career information from Kreativ journal) supported the existence of an age gap in full service advertising agencies.
} 
Szelényi and others have argued that Hungary's economy is a case of "capitalism from without," that is, brought about by actors who are not the historically identified capital-owning class (Eyal, Szelényi and Townsley 1998). In this historical formation, "the hegemonic role is played by foreign investors, who rely on domestic expert-managers to run their local operations" (Szelényi and King 2005). Hungarian advertising, indeed, exhibits these properties in its reliance on recycling "socialists" and recruiting youth to organize a market dominated by international owners.

\section{The elders}

The older group is entrenched in socialism, yet surprisingly it has also amassed experience in capitalist business administration. These professionals are often called, whether in praise or critique, "the profession's great elders." They are in their fifties and started working in the advertising department of one of three state-owned companies (MAHIR for domestic publicity, Hungexpo for foreign representation, and Skála-Coop, Budapest's main department store chain) in the 1970s. They were mostly trained in Marxist-Leninist political economy or trade (this economic background is regardless of the elders' current specialization as kreativ director or account director), and some got formal education in advertising through a course by the Ministry of Domestic Trade. They built a career in and of socialism, since socialist advertising not only had to influence the sales of goods as an industrial policy tool, but often it was used as propaganda for the values of socialism (Patterson 2003; Abrams 2007). The typical message was "Buy shoes from the shoe store," other ads promoted dairy products or a major department store, and taught people how to use the country's savings bank more.

However, these "elders" had apparently acted as innovators of their time and, not unrelated to this, they had some knowledge about western practices. They read whatever western advertising material they could put their hands on (Hermann 2001a), and these young socialist ad-makers tried to mimic the organization of western ad production, forming the first kreativ teams. They often had the support of their politically appointed superiors, but often confronted them or proceeded in clandestine ways.

The "elders" had been well into their careers when the organization of advertising shifted from an exclusively state-owned program in large bureaucracies to increasing private ownership of western-style advertising agencies. Performing an individual level "recombination" of their assets and liabilities (Stark 1996), some socialists managed to continue into the new economic arrangements. Some of them left the state ad departments and established their own advertising businesses, taking the clients they served (state monopolies) with them. At the same time, a legion of world-famous international agencies such as Young\&Rubicam, McCann-Erickson and Ogilvy\&Mather rushed into the Hungarian market, following and anticipating the eastward expansion of their global clients. ${ }^{33}$ By the mid-1990s all the large global ad houses were present (Kreatív 2000).

\footnotetext{
${ }^{33}$ Today the global advertising market is highly concentrated so that multiple legendary ad houses like Young and Rubicam and Leo Burnett are now owned by the same global group such as WPP or Publicis (Grabher 2001), while still competing on a given market.
} 
In the late 1980s selected socialists were recycled by the transforming economy, and went on to become heads of capitalist advertising businesses. During this time, international ad houses entered the Hungarian market in three ways: by founding entirely new branches, or by buying the state-owned ad departments or the privately owned startups of venturing young socialists. The internationals imported foreign management and mixed it with the locally grown, hiring young socialists to leading positions. $^{34}$ The latter tended to stay on in those top positions until recently. Today the "elders" still manage market-leader international agencies, teach advertising courses and workshops, operate as communications consultants, sit on ad festival juries, and lead the four professional organizations. The common socialist past is not forgotten: "Members of the Mahir crowd maintained and continue to maintain good relations with each other", said a former MAHIR manager (Hermann 2001b).

\section{The transitional generation}

There is a noticeable gap between the oldest group and the cohorts that will be called the "transitional generation" (Stoilkova 2004), who are now in their thirties and early forties. ${ }^{35}$ The young professionals are steeped in the west, looking to it for ideals of conduct. They also take capitalist norms of doing business much more for granted. Many of the transitionals were the first to study under revised curricula that were tailored to the new needs of the market. ${ }^{36}$ While "the ruins of communism were not a tabula rasa" for sure (Stark and Bruszt 2001), it is important to note that subsequent generations were increasingly shown into the new rules of the game as the only game ever played.

Members of this generation virtually became consumers before they were capitalists. These relatively young Hungarians spent their adolescence in the world of "socialist consumerism" of the 1980s (Vörös 1996; Hammer and Dessewffy 1997). While consumption has figured more importantly in all socialist regimes than has been commonly thought (Reid 2000), "goulash communism" or "frigde socialism" in Hungary was especially a period of relative abundance of consumer goods. These were delivered by the socialist state (in exchange for growing international debt), by the strengthening semi-legal "second economy" (Rona-Tas 1997) and by small-scale cross-border illicit trading practices (Gecser and Kitzinger 2002; Hammer 2002; Wessely 2002). Most prized among all were the material and cultural goods coming from the west (Hammer and Dessewffy 1997). In addition to

\footnotetext{
${ }^{34}$ While some ad houses such as Saatchi\&Saatchi or J. Walter Thompson brought foreign management, and international agencies all brought creative workers from the "west," they also built heavily on the local knowledge and connections of the most western-oriented socialist advertising workers.

${ }^{35}$ This is different from the "last Soviet generation" identified by Yurchak (2006). The latter refers to cohorts that came of age in the 1970s-1980s, while here we mean a later set of cohorts that entered adulthood in the late 1980s-early 1990s.

${ }^{36}$ One important part of the transitionals' habitus is the skill of self-presentation for the job search. For older people after socialism there were CV-developing workshops where participants were taught how to present themselves, what kind of information belongs on the resume and how it contrasts with previous customs of public identification (Larson 2002). The "transitionals" learned all this straight in the forming job markets of the early 1990s. They were new workforce but everyone else was just as inexperienced at how to do capitalism. Later cohorts of transitionals learned about proper self-presentation already at school.
} 
the influx and subsequent consumption of western goods and youth culture (Garofalo 1992), there was an increasing outflow of students and travelers to the lands of plenty (Gayer 1998; Dessewffy 2002). Thus, the transitional generation is immersed in western culture to an incomparably greater extent than their older counterparts.

From the 1990s, young Hungarians with certain assets were hired en masse to the incoming international advertising firms. "We were sucked up into the industry [referring to a vacuum cleaner]," as one current agency leader put it. The most desirable asset for that industry was one's relation to the west, so that English skills and experiences "abroad" worked to one's advantage. The "elders," who were now suddenly managing the new offices of international ad houses, were in charge of hiring and looked for "virgins" to advertising, as one elder phrased it, adding that if you spoke English and were intelligent, you were hired into the newly created jobs of kreativ and account. English was important because it is the language of communication within international agencies, with foreign bosses and often with the client firm's marketing department, which had very often been staffed with foreigners in the 1990s.

Educational background of the "transitional generation" illustrates that no specific experience or training was required to enter the new advertising market in the early 1990s. In the sample, eight out of the nine practitioners without college degrees (at entry) are from the transitional group, and yet they occupy respectable positions at international agencies. A large proportion of young professionals (13 out of 56) have humanities and social science backgrounds, not entirely unusual for creative copywriters, but surprising for account managers. The central place of language proficiency is visible in the number of English teachers among both kreativ's and accounts. The major difference from practices in the UK/US is in the hiring of the "first" advertising workers, when accounts came not only from business but from very varied backgrounds and kreativ's even more, many without degree. While higher education is not always a requirement for creative jobs (yet paradoxically, creatives are considered to be the "purest" ad professionals), it often stands as a proxy for verbal eloquence and "grammatical correctness" for copywriter creatives (Dávila 2001), and for technical capabilities of visual creatives. ${ }^{37}$ With an increasing supply of English-speaking credentialed Hungarians, today agencies can afford to only hire college graduates.

Originally they knew nothing about advertising, so early members of the "transitionals" were trained on the job by both the elders themselves and the imported "foreign" executives. The elders were active in the training of the next generation outside the workplace as well, setting up workshops and courses where a great part of the current transitionals passed through. The early transitional cohorts rose to the top ranks quickly - due to the lack of predecessors above them, to the expansion of the advertising market, and to the gradual departure of foreign agency managers. Most of these early transitionals are now in top-tier management: they are

\footnotetext{
37 "Art directors" have more or less consistently been hired from the country's two industrial arts schools, which provide technical training. An ex-patriot art director (with a UK degree now working in Hungary) observes that Hungarian applied arts education is not as "concept-oriented" as Western European schools for advertising design.
} 
CEOs, client service or account directors, kreativ directors, and owners of (typically small, entirely Hungarian-staffed) agencies. They take administrative positions in professional organizations and sit on the jury of advertising festivals. ${ }^{38}$

The typical career trajectory for the early "transitionals" was to start at international ad houses (that were coming to Hungary and setting up branch offices) and to stay within that circle. The other route was to found one's own agency, which happened in two ways. Around 1990 some young Hungarians started small agencies without any background in advertising. Many of those early ad shops perished, but the few survivors are the largest and most successful Hungarian-owned shops today. They compete with the internationally-owned houses both in terms of clients and recruitment, to the point where they are snatching employees from the "multi's", as Hungarian-owned agencies like to call their internationally-owned competitors. The second way was to leave an international agency in mid-career, having attained the know-how, to found one's own - a method popular throughout the 1990s. As we go towards the younger end of the transitional continuum, the picture becomes less "fuzzy." Entrants within the past 10 years have a more structured experience from those who entered advertising in the turmoil of the early 1990s. Social relations have become more closed and advertising expertise less readily accessible by "laypeople." ${ }^{, 39}$ First, the younger the professional, the more removed from socialism and the more immersed in western knowledge, which has of course become everyday knowledge for the later post-socialist cohorts. Second, the new types of careers and identities of post-socialism have become more visible and more predictable as advertising jobs and tasks are now fairly well established. Third, latecomers face increased competition and higher barriers to entry. ${ }^{40}$ The selected tend to have higher qualifications than their older superiors: accounts especially often speak multiple languages and went to the better colleges in Hungary, to English-language business programs, or to Western European schools. ${ }^{41}$ In fact, the youngest participants of advertising (entry within the past 5 years) often consciously prepare for an advertising career at school and envision advancement in the tracks laid out for them. But these transformations have been gradual and there is no clear divide

\footnotetext{
${ }^{38}$ These socialist and transitional trajectories and the accompanying institutional changes are consistent with earlier findings that the economic elite's replacement was slow in general and fastest in the private (versus state-owned or privatized) sector, where the new elite was also younger than in the other two sectors (Böröcz and Róna-Tas 1995).

${ }^{39}$ This process is commonly referred to as professionalization. I do not rely on this term here in effort to cast the problem in the larger framework of expertise and fields of cultural production, and also because we are interested in the diverse notions of "professionalization" for the different actors, and not as a problematic normative idea, as Abbott has pointed out (Abbott 1988).

${ }^{40}$ Specialized programs in advertising are increasingly offered in Hungarian business schools, but not in applied arts schools like in Western Europe. Typical hires are no longer "virgins" to advertising. Account managers in the sample who were hired in the past 4 years all have degrees in marketing or advertising. Trained and ambitious students are pouring out of the roughly 70 marketing programs of Hungary, a large number for a country smaller than New York City's population. Agencies can select from this pool and they now prefer to take people first as interns, mainly from the English-language business schools. Advancement on the organizational ladder has also slowed considerably; there are much fewer spectacular careers.

${ }^{41}$ Bandelj and Purg argue that the mushrooming private business schools in Central Europe are catalysts of change as they "contribute to the diffusion of market-based knowledge into the post-socialist region," helping "actors learn to become market players and, consequently, help to build capitalism from the bottom up" (Bandelj and Purg 2006).
} 
within the "transitional generation." In addition, those who entered the industry within the past 5 years are in lower organizational positions and related to this, they are not yet influential in the debates at hand.

The groups' trajectories show that advertising professionals' dispositions towards capitalism and the west already started forming under socialism. A reason is the role of ongoing interaction between the Eastern bloc and the West, despite their official separation in the Cold War period. Through countless channels of cooperation and exchange, the penetration of the Iron Curtain reinforced the concepts of East and West at the same time that it deconstructed them (Eyal 2000; Bockman and Eyal 2002). Thus, by the time Hungarians became part of the post-socialist advertising business, they had been equipped with views and expertise about the west.

We were able to separate two successive groups of professionals based on their entry to advertising and their distinct trajectories. The elders are experts of socialism first and more recently, of capitalist business organization. We also found that they were frontrunners of westernization before the young generation's arrival. The "transitional generation" is expert of the west above all - of culture in general, and making capitalist advertising in particular. For them knowing the west is second nature, while for the elders it is a more "learned" habitus.

In light of debates about women's empowerment in post-socialist economies (for an overview see Weiner 2007), it is an interesting question to what extent the professional struggle is gendered. We could expect that women would be located closer to the "profession as service" position based on previous research. ${ }^{42}$ However, I find the contrary: young women typically align with the promotion of professional autonomy, while the older women certainly identify with hardworking professionalism. In short, women do not seem to share a view of their profession that is distinct from men-even when they voice observations about gender inequality-rather they replicate the generational split, which leads to the above mentioned ironies. ${ }^{43}$

\footnotetext{
${ }^{42}$ Women have been more likely to hold service-oriented jobs, which are in turn often viewed as lower status by others. Indeed, account managers in advertising are typically female, while creatives are overwhelmingly male (not just in Hungary). Second, Weiner (2007) has found that young female managers in Poland are wholeheartedly willing to take responsibility for meeting the high demands of a business career. Boyer (2006) and others have found, moreover, that female managers and professionals in post-socialist countries adopt a professional discourse that is devoid of gender concerns.

${ }^{43}$ Younger women in Hungarian advertising are just as likely to favor professional autonomy as their male colleagues. Many stated as a matter of fact that they would have to leave advertising if they wanted to have children because the workload is unmanageable, and agencies do not support maternal leave. Importantly, this gender-specific observation blends well into the young generation's general criticism of work expectations in Hungary versus western advertising. Young men in advertising are just as likely to complain that in the west one has normal work hours - they know from colleagues-whereas agencies' clients in Hungary dictate an inhumane pace of work.

In fact, it is the older women-whose careers started in socialism - who are more likely to represent profession as service, partly due to their particular careers, namely that many of the "socialist elders" had children first, and got into advertising only after an extensive maternity leave granted by the socialist state in the 1970s. With the question of mothering behind them, as top managers they are now dictating a fast work pace for everyone. This is not a necessary outcome - they could have been at the forefront of fighting for childrearing concerns, to preserve socialist welfare benefits. But they were not well-positioned to argue for welfare since young competitive professionals could have objected that the older women could not move on, that they are stuck in socialist times, when a paternalistic state and corporations sheltered inefficient employees. Instead, the older women have turned into the strong managers who demand a lot from their young employees, and describe professional work in the kind of universal terms that erase the gendered nature of a profession (Boyer 2006).
} 


\section{The waxing and waning of expert groups: positioning between incumbents and challengers}

Careers treated in isolation, however, yield inconclusive results, as I argued above. Based on expertise that we derive from an actor's career, we could argue both ways about the views the groups would take. There are factors that push and pull them towards both the autonomous and the dependent (market) pole of the field. The western expertise of young professionals could equally prompt them to promote market values, and not to educate others about respecting creative work. After all, the west is just as much the perfect market as anything and the "transitionals" have experience with its organizations. One could also reasonably expect that the elders' experience of socialism - even in Hungary education and careers were certainly not market-oriented-combined with their earlier role as "vanguards of creativity" would push them toward the creative-autonomous pole of the field. In fact, their central role in building the "new" advertising industry would suggest a strong prowestern position. The fact that the elders still train young entrants into advertising is based on their identification with advertising as distinct creative work and with a mission to educate everyone about the greatness of the profession. So why don't the elders identify with the educator mission?

To arrive at the final answer we need to understand trajectories as dynamic relations of the field. Fields are sets of relations organized according to contradictory principles. This means several things. First, actors are engaged in a positioning game and choose or create positions for themselves - while they are limited by the range of possible positions and their equipment with capital (expertise). Second, if one part of the field changes, the rest must change with it. Hence, past positions of incumbents may be altered when newcomers arrive and claim their expertise. Third, no position and position-taking is stable because actors are in a double bind, and they cannot commit to only one principle for long. Due to the hybrid nature of the field, any one-sided claim based on artistic autonomy or business interests is vulnerable to critique from the opposite side - apart from being attacked on its own terms. ${ }^{44}$ For example, advertising produced l'art-pour-l'art (in order to win creative festivals) cannot be the only output of an agency if it wants to survive. Yet too much focus on what clients request may yield less originality (because clients typically do not prefer untested ideas). Actors exploit this built-in ambiguity of professions to justify themselves and to denounce others.

Thus, by looking at the historical dynamics of the field we can describe shifts in the relations of the groups, resulting in changing roles of incumbent and challenger in the field. Currently young professionals argue that the west is the best, while older professionals say the west is overrated. But has this always been the case? We find that in fact, the "transitional generation" pushed the elders out of the "western expert" position. When a more western-minded youth entered the professional scene in the early 1990s, they posed a threat to the elders' competence about the west and

\footnotetext{
$\overline{44}$ McFall (2004) also observes that advertising is a hybrid of "culture" and "economy," but means culture broadly as the general practice of meaning-giving. While I agree with McFall's thesis, there is a more specific hybridity of advertising that comes from culture more narrowly understood as cultural (mainly artistic) production.
} 
the modern. Indeed, the younger professionals are able to use the west as reference in a way that socialist professionals simply cannot match (e.g., by speaking the languages better, and by having studied or worked there). The young who arrived along with the new market arrangement found others already there, whose competencies they had to consider in devising a strategy to gain control. They came to define the advertising profession as creative autonomy like in the west, in response to the elders' own claims to western expertise. This movement coincided with the elders' increasing expertise in business. The elders, who were once dominating but are now in minority, formulate their views to respond to their challengers' claims. They shifted from vanguard of western creativity to defending clients and criticizing the "west" as a unified, superior model.

In the preceding sections I devised an explanation, with the help of a new approach to professions, for why advertising professionals are positioned in the inverse pattern that was observed. I concluded that the particular structuring principles of the Hungarian advertising field, namely the tension between autonomydependence and the succession of old and new logics (and populations), align the young with the desire to educate about the west, and the old with serving the client.

In the following, I present empirical evidence to support the argument that this outcome is the result of the operation of a field of expertise. First, I add more depth to the opposing definitions of profession, that of "educator of the west" and "service," and show that they can be attributed to the "transitional generation" and the elders, respectively. Then I demonstrate how the relational aspects of the field result in back-and-forth maneuvering between the two groups, supporting the claim above that position-takings are not stable.

The strategy of the "educators": embrace the west and blame the client

"The clients should be educated [by us ad professionals]," says the owner and manager of a successful Hungarian agency. Let us see this position-taking more closely. It is a strategy to justify the role of the advertising profession to its audiences, and it is criticism that entitles the young to the mission of transforming the actors around them: their clients and consumers. The educators acknowledge with disappointment that although the advertising profession knows what is creative and modern, knows about taste and how to make good ads, Hungarians won't listenthey are satisfied with low quality. The effect of socialism is emphasized and the old mesterek (masters) ${ }^{45}$ are implicated in holding back the profession's development.

There is by and large agreement among young professionals on the superiority of western creativity and autonomy in advertising. Within the group, older "transitionals" identify with the "educator" position most clearly. The adherence of the most recent entrants, mentioned above, to either of the profession's logics is more difficult to establish because their responses are more mixed. The two older groups seem to be competing for the alliance of the youngest professionals whose views

\footnotetext{
$\overline{45}$ This term refers to the idea that the relation between younger ad professionals and the "elders" is that of master and apprentice. The older generation labels themselves frequently as mester, and it is used by loyal students, but also ironically by young professionals who are critical of the elders, even if the latter had trained them.
} 
have not yet solidified. A starting point for future analysis is that there are voices among the youngest professionals praising the old socialist times-distance from socialism enabling nostalgia (Patterson 2004).

The signature diagnosis of the state of Hungarian advertising by young respondents is that "international ads are much better than Hungarian ads, in general," announced this time by a creative director at an international agency. The professional standard is indisputably the west: "I never look at Hungarian ads for inspiration, only foreign ones," says a young art director working in a small Hungarian agency. They keep track of the "foreign" scene because, in the words of an account director at a large international agency, "it is important what the trend is, and which direction they are moving abroad. We are behind here by decades. And it is good to see how it is over there. What we can reach sometime, once, perhaps."

What do young professionals mean by "good advertisement"? It isn't always clear or consistent, but mostly they refer to style. Aesthetically graphic features should dominate and text is minimal. The ad should be smart or audacious, or funny in a daring or in a subtle way, and the consumer is invited to play and figure out the message which is not obvious but powerful. ${ }^{46}$

When discussing the reason why Hungarian ads are bad, young professionals blame the ad production process and consumer taste. They transform the general problem of creative autonomy in advertising into a specifically Hungarian issue of development. Through the lens of development the educators see unripe conditions for autonomy. Hungarian advertising is a "young profession," and it is behind the west. The lag can range from 3-4 years to decades depending on the speaker, and implies that Hungary is temporally (delay caused by socialism) but also spatially (East Central Europe) and as a result qualitatively, far from the west. The owner of a small but highly regarded Hungarian ad shop lays out the map:

England-London, London and Berlin are the most influential places... These are the centers of trends in style... The center of the ad business and of marketing is America, but in visual the trend is London, that's clear... Berlin is like when a drop of water falls into a pond and where it falls in is London, it makes big waves, where the waves cease and you can't feel almost anything, that is Budapest... Going abroad is inspiration... This is how it has been for 150 years, Széchenyi too went abroad and he was filled up with energy so much he was ready to burst. ${ }^{47}$

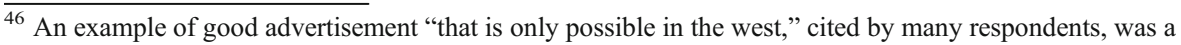
Nike ad called "Ole!" The TV spot (not aired in Hungary) features the Brazilian and the Portuguese soccer teams preparing for a game. Superstars Ronaldo and Figo start teasing each other, showing off their skills with the ball. Soon both teams are involved and a beautiful game unfolds before the official whistle. The players perform sensational tricks, the air is sizzling, crowds are cheering and the referees unexpectedly join in the game; all to a laid-back mambo song (Nike 2004). The Nike shoes or other sportswear are not emphasized in the shots. This is the kind of professional standard to which Hungarians measure themselves.

${ }^{47}$ István Széchenyi is the symbol of reform in Hungarian history; a public-minded aristocrat who fought for the modernization of the Hungarian economy in the mid-19th century. All high-school students know that Szechenyi's ideas and programs were inspired by regular visits to England and other "developed" European countries.
} 
Calling western advertising "mature" signals what educators think of the socialist period. Some acknowledge that Hungarians have made great progress, but now the problem is that they are trying too hard, so that "the Hungarian ad has been overstrategized," according to the kreativ director of a large international agency. Another kreativ direktor at a similar agency says Hungarian ads "smell of sweat" and are "not yet elegant" like foreign ads.

To close the gap and to become the west, young ad professionals feel others must be taught how to be proper clients and consumers. Distance from western quality, it turns out, is the fault of clients and consumers. The west is where advertising "has much greater prestige," it is not a "servant profession," and it is not "subordinated" to its paying clients. As a young account director at an international agency jokingly describes, in the west if I am a client "I pay the agency this and this much because they are the professionals, they know communication, and then I am not going to interfere-why doesn't the bunny jump from left to right, and why isn't it blue instead of red..."

According to this common standpoint, "there" the client doesn't intervene but listens to the advertising professional, creativity doesn't have to be compromised, and dignity can be preserved. The following tirade by a young strategic planner shows how frustrated young professionals feel because they are bound by "unprofessional" business partners: ${ }^{48}$

There aren't as many good ads [in Hungary] as could be, and a lot of good creative material that could be put out isn't put out, and this is because of the decision-makers, because they simply don't dare to go with it, because they don't know what is good and don't feel where they should be heading, and it is this unprofessionalism, that is, this stratum has not matured enough to be able to decide between good and bad.... Marketing managers are struggling with an inferiority complex. As soon as they have a tiny bit of power, they very much try to take advantage of it-instead of taking care of the brand (brand).... I know English, French ... German colleagues, in fact Italians too, just to mention Southerners - there you don't have this ... that "I'm bossing the agency around, and the agency is my batboy (csicskás), and I tell them to have the material ready by tomorrow, and then it has to be ready by tomorrow," this doesn't exist. There the agency is a partner. [my italics]

In these typical tirades ad professionals play off the two kinds of audience against each other. Towards both peers and consumers, the justification of why Hungarian ads are not entertaining and winning international awards, is built on criticisms of the agency's client. It is the client who treats the consumer as a dupe by not risking modern design. Good advertisement ideas by ad professionals are defeated by the client's anxiety to make the ad readily interpretable for the consumer, educators say. Respondents often cited a recent conference presentation that demonstrated, through the fictitious negotiation process of an ad, the typical move away from this ideal as

\footnotetext{
${ }^{48}$ While blaming the client for weak advertisements is the most powerful self-justification among young professionals, it is difficult for them to explain the uniqueness of clients in Hungary compared to those in other Eastern European countries, which are similarly "backward" markets and yet perform better than Hungary, according to the professionals themselves.
} 
the client takes over the design. To advertise a well-known small-sized car in a print magazine, the agency's proposal was to have a very small car in the middle of a clear background, and in small font: "Think small." No logo, no other explanation of features. By the end of the caricatured client meetings, the final version had a huge photo of the car, lots of text, the company logo in the corner, and in large font: "Think big." Ironically, the presenter was a guest from Western Europe, so client intervention is apparently a problem in the west, but this contradiction did not keep respondents from talking about superior western ad practices.

Young professionals, however, also believe that Hungarian consumers are not ready for the modern. An art director of a small Hungarian-owned shop broods over the fact that "reception [for good, humorous and daring ads] is very limited... Even though our mission, besides making advertisements, is to change ways of life, lifestyles, ways of seeing ... into modern - today's style." This under-appreciation by the audience is again due, in the educators' mind, to the developmental delay. Consumers in the west understand sophistication and they behave properly, as consumers should. First of all, westerners have "brand loyalty." This common complaint is voiced by an account director at a large international agency to illustrate the difficulty of doing ads for Hungarians:

So in western societies the purchase of an everyday consumer good does not depend on how much a kilo of washing detergent costs, but rather on the image, and other things... If you collect the proofs of purchase to earn a baseball cap or a towel, you'll be laughed at abroad.

Educators often bring what they see as this petty, calculating, backward mentality of Hungarians to justify why ad campaigns do not work on their consumers. If consumers are indifferent towards the signaling power of brands with respect to identity building and go instead for sheer price, then all advertising can do is wash its hands.

Second, consumers "over there" are conscious and morally responsible. Unlike Hungarians, westerners know moderation, remarks the owner of a small Hungarian ad shop:

This is the product of the transition: Hungary is still in the phase of accumulation [of consumer goods] ... people can't get enough of buying because they can, because under socialism they couldn't get everything all the time... When they have accumulated enough, they will get tired, and they will realize that they need real values, not mass values.

We see again how professionals maneuver in the triadic relationship. Here is an alternative story about why Hungarian ads are poor, which does not feature the client. Now it is the consumer's pre-modern attitude to ads and behavior as a shopper that is the cause. The Hungarian people are displayed both to peers and this time, to clients, in defense of why Hungarian advertisements end up being low quality.

Finally, educators accuse peers of not cooperating and of selling out to clients - in other words, for being overly competitive and client-oriented. Some professionals condemn the advent of cut-throat competition among agencies and the lack of professional cooperation to fend off merciless clients - who depress agency fees. Such cooperation is not only found in the west ("you only have to go as far as Austria," says 
the young CEO of a large Hungarian agency), but also in the past. Some agency leaders reminisce nostalgically of the time "when it all started," meaning the early 1990 s, which apparently was a period of high fees and great profits. ${ }^{49}$ Instead of pulling together, other professionals observe bitterly that "certain" agencies sacrifice professionalism. In the words of an account at an international agency:

Quote-unquote professional prostitution for the money. So, a lot of people have given up professional quality in order to keep clients. And this, unfortunately, has not elevated the professional level. So, they will do anything for the client, as long as they pay....

When educators do consider the market aspects of advertising, they frame Hungary as a "small market" or as the common phrase goes "small country, small soccer" (kis ország, kis foci), to suggest that the reason for the low quality of Hungarian advertising is the lack of funds; it is not worth to invest in a small market of consumers. But while this argument may hold true, it falters when Hungary is being compared to the excellent output of small western countries - a contradiction that respondents reconcile by switching to another argument: those are small but wealthier.

The strategy of service: deconstruct the west, embrace the client

The ex-socialists are actually educating the young capitalists about the principles of capitalism. Taking the position that frames advertising as a service profession, the "recycled" socialists, the elders tend to accept the market setup of advertising. They disapprove of what they see as a common misperception in Hungarian advertising nowadays (i.e., among their younger colleagues), which is that professionals do not sympathize with the client and undervalue Hungary vis-à-vis the west. So the older professionals urge to cooperate with the client, creativity being inclusive of the client's needs. They urge professionals to accept responsibility instead of framing the problem as professional autonomy. An older generation kreativ sums up:

What I experienced in the profession ... is that we are much more talented at looking for excuses than at actual creative work. Here in Hungary today everyone blames the client, everyone blames the person in the next room, but never themselves.

In fact, they argue it is clients who can teach one how to be a professional. Here the elders bring the market logic against the educator role to humble the young. According to the older account director of an international agency,

One can learn the most from good clients. So one learns in the course of everyday work...you can learn how to receive a task; you can learn what expectations a client has; you can learn how to accomplish a task; you can learn about the different product categories; you can get to know the analysis of different areas, of the competitors. So if agencies prepare based on the expectations of clients, [those are so high that] the agency will have mastered the knowledge of the area in question.

\footnotetext{
${ }^{49}$ Speaking of Hungarian advertising as if it had started only in 1990 is typical of the young professionals' stance on separating socialism from post-socialism.
} 
What is more, professionals are not only not qualified to educate their clients, but they are not qualified to teach consumers, either. According to the client service stance, advertising is wrong to see consumers as dupes and overstates its own role in bringing the modern to Hungarians. The educators should accept that advertising has a limited role and accept consumers the way they are. One of the "elders," a kreativ director explains that

[t]he big misunderstanding in Hungary, and I'm exaggerating now, is that a commercial still contains [explicitly] the information that Nike is a kind of shoe. So we think that the Hungarian consumer is dumber than the consumer abroad. Well, no ... the consumer is also universal.... They all know and desire these brands... It's a different question why you need to look the same in Budapest as in New York, but this is what they would like, and we're living in a free world. So we can say that especially those [consumers] who follow the fashion trends will hear about such information earlier than advertising brings it to them. [my italics]

As visible in this quote, while the young build an ideal of the west, the old are working to show it is a myth, for three reasons: we cannot generalize; things are global; things are local. Elders manage local and global by bringing them to the same level: by decomposing stereotypes, by rendering the global into a set of localities comparable to our own. The same kreativ later emphasizes that

There is no such thing as "the English ad" or the boring German ad. They have good ads too, just as there are many bad ones among the English ads as well. There is no such thing as "the English ad," it is just as much nonsense as when they say that French women are the most beautiful in the world.

Thus, for the service position the "west" that everyone worships does not really exist as there is nothing generalizable or superior about it. Professionals who share this view often declare "there are good and bad ads everywhere." Hungary is no different, no worse or better than, anywhere else. An older account director cautiously replies:

$Z s V$ : How do Hungarian ads compare to foreign ads?

-You mean quality-wise?

$Z s V:$ Yes.

-Well, in my opinion this is another one of those things where you cannot generalize. So, this profession has accrued 15 years of experience, and within that period there have been really good periods. I think today's climate does not favor great creativity...I don't know how we fare in international comparison, because all in all, those... ads that you see, for example ad festival winners, cannot be compared with ads made just on the Hungarian market, since those ads are obviously the result of a certain kind of selection, so you can see really ingenious ads, but, but if you compared, say, Hungary with Austria, or one other country at a time, it's not sure that we [the Hungarian ads] would be worse. ${ }^{50}$

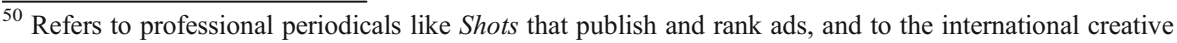
festivals, of which the most important is the annual festival in Cannes.
} 
Turning around, service-oriented professionals will often argue that some market properties are simply universal. To educators' protest that clients exploit them they respond that "clients treat advertising poorly everywhere," implying that we cannot simply blame poor Hungarian ads on them. Both the above kreativ and account cite a "global climate" or trend that determines conditions for advertising in Hungary. Further, against the educators" other claim that Hungarians are "behind" as consumers, the service position brings the idea of a universal consumer, as the quotation above illustrates.

In a move to protect their turf, however, service-minded professionals warn that it is just as dangerous to disregard the local as to be oblivious to the global. Advertising must be adapted to Hungarian circumstances and those who fail to understand this make a big mistake. The older generation top managers think those international agencies do it right that rely on locals to navigate the Hungarian history of clients and consumers. This is not surprising given that they themselves are those locals. In the elders opinion, the other big name agencies that try to impose their own western staff and disrespect local knowledge are doomed to fail. In agencies where they attempted this, says the above creative director,

-A lot of tragedies happened. Agencies like that still exist, for example [company name], where the entire management consists of foreigners, and ... $80 \%$ of employees are thinking of leaving, even though it isn't easy to do in today's job market in advertising.

$Z s V$ : And why is this, that it doesn't-

-Well, because they have no idea about Hungarian culture, not high culture

but Hungarian behavioral culture itself, the chemistry, and so on and so forthso they can't.... [trails off]

The creative warns foreigners that they must craft their relationship to Hungarians so that, in network terms "global links do not loosen local ties" and essentially prescribes partnership, as the recent typology of working global-local integration in the field of civic associations calls it when local firms act not only "as agents of foreign [NGOs] but as collaborating interlocutors" (Stark et al. 2006).

Maneuvering past socialism: historical dynamics, loose coupling, and legitimating expertise

The explanation for why groups of actors are coupled with sets of views on profession-education versus service-is not a static model. The two groups' trajectories and hence their strategies do not exist independently. Rather the young educators and the old service friendly exploit the vulnerabilities of each other's positions to counter each other's claims. From this relational nature of positions we can see two related dynamics: 1) how the advertising profession mediates large-scale social change through the old and new groups' representations of socialism; and 2) the "loose coupling" between actors and views.

The dispute about whose expertise counts culminates in the question of socialist legacy. The advertising profession mediates large-scale social change by sanctioning certain types of knowledge and discrediting others, most notably through narratives of what happened around the "regime change": How new is the new, how much 
change was there, how fast? There are actors who emphasize abruptness and their opponents who insist on the gradual nature of change. Struggling over the meaning and significance of "transition," the young educators draw a strict line between socialism and capitalism, while old professionals counter this by narrating continuity. ${ }^{51}$

The educators' argument is that advertising is a new profession with a new type of knowledge (western), and a new relation towards clientele (autonomy) - hence, the need for educating everyone about it. Most young professionals take for granted the idea of a "generation change" in advertising, and diminishing the stature of the elders is intertwined with the idea of a new regime. For young educators the birth of advertising in Hungary coincides with their own entry into it, and they are pushing for the west as the relevant expertise in this forming profession. The young educator thereby downgrades her mester. A frequent declaration saying is that "there wasn't any advertising in Hungary before the transition," meaning that the old players are not competent in the new expertise. Many young agency leaders agree with an account director at a large international house that a generation has grown up that knows how to make ads professionally, implying that the way they do it is the way it should be done:

[Ad-making] has its method, and there is a generation here that has grown up in that method, who has experienced it, and who does it on a professional level.... About a month ago Kreativ asked around the question whether there will be a generation change (generációváltás) in the profession. The "great elders" [lists names], [name] was kicked out of [agency name], well, poor thing doesn't know the first thing about how to make ads. Very nice person, and a professional, but has nothing to do with ads whatsoever.... There is this Great Generation, there is [lists names]. They were and still are the CEOs of [companies]; who knows for how long yet. There is [name] who does not do ad campaigns anymore, only training sessions. [Name] was also sent away from [agency name]... [names] are still there at [agency name], they are these old pieces of furniture. [my italics]

The elders, in turn, deploy various models of transition. Their strategy is similar to that of Polish shop floor workers (Dunn 2004): to get around the socialistcapitalist dichotomy that renders them invaluable. They commonly argue that advertising had been an existing profession in Hungary from socialist times, the expertise is not so novel, and therefore they are entitled to a high status in today's professional order. The elders emphasize that they actually knew everything about advertising already before foreigners arrived to the country; the west cannot teach them anything they didn't already know. An ex-socialist kreativ observes that when their Hungarian startup was bought out by a large international ad house at the beginning of the 1990s,

The interesting thing was that our thinking, and this in fact probably sounds ridiculous, but we didn't receive much in the way of new things, I mean in terms of knowledge. But everything that we thought about this profession was confirmed.

\footnotetext{
${ }^{51}$ Interestingly, no one mentions pre-socialist advertising. Hungary had, like other European "bourgeois" democracies, an extensive advertising culture in the first half of the twentieth century, following the German and to a lesser extent the American model for the organization and style of work (Abrams 2007).
} 
Discounting the new-western in this way is also a response to the young generation's claims that the presence of foreign experts in Hungary has been beneficial. The idea of learning from westerners is exemplified by the following confession from a young account executive:

... professionally I learned everything [at the international agency]. I can say that I got there at the right time. There were a lot of foreigners here at that time, who, of course, grew up in the established cultures, and I learned so much from them. Today only a few people have such luck because the tendency was, when these international agencies were set up [in Hungary], that the first generation was filled up with foreigners to train and educate the Hungarians, and if today you get into an agency, you don't meet many foreigners, which I think is a loss. [my italics]

The other narrative of continuity is fluid transformation. It allows elders to accept the validity of a new expertise while maintaining that socialists adapted to it rather well. An example is the following magazine interview with one of the elders who is currently leading a professional association:

Kreativ magazine: How did the people who left MAHIR make the professional shift? Was adaptation easy when they got into a new environment, a new system?

-Örs Megyer: I don't think there were particular difficulties in the adjustment. There are several reasons for this. For one, the Hungarian economy did not change from one moment to the other, but it went through a very intensive, yet continuous, change. The shift of perspective in people was also a process. We had to get used to the fact, however, that we had found ourselves in a strict, capitalist (tökés) world, where there are serious tasks and reporting, and where you cannot share responsibility with anyone else. (Hermann 2001a my italics)

The journalist is pushing a strong version of the new/old divide by using the phrase "new system," but the interviewee gets around this confrontation. His larger point is that if transition is an incremental process, then its previously socialist participants are just as legitimate members of the "new" economic organization as are the newcomers. Meanwhile, the "socialist elder" is navigating to demonstrate his understanding of the contemporary social order and the relevance of his past competencies. Importantly, he is using the word tökés rather than kapitalista. Both are Hungarian translations for capitalism, but tókés is the old translation of capitalist used in the original Hungarian translations of Marx, and it was a favored derogatory term in Communist Party discourse. It is no longer in common usage, and its invocation will generally be interpreted negatively, qualifying the speaker as an extreme leftist or as anachronistic. From the mouth of an ad agency leader it is the latter.

Using this idea of seamless transformation, the elders can acknowledge the divide between generations without accepting the socialist-capitalist discontinuity, in a way that reconciles their presence at the top with the up-and-coming new generations. This is done by highlighting advertising experience instead of creativity, by referring to their own role as mester (master), as trainers of the young. This frames elders as 
incompatible with the young's expertise, as something the young depend on and cannot acquire. ${ }^{52}$ An older account director explains why there is no conflict:

The older generation's task is to educate into being a new generation, ... we don't even need to give them our seats.... We are not alternatives to each other (the new and the old), so we can work together in a good combination ... up to a certain point, and we [elders] have to feel when that point is... and when the right team comes along that can take this over from us, then we will give it to them, of course.

The battle over historical continuity points to the second dynamic of the field noted earlier, namely that the positions polarized according to market dependence and professional autonomy are not that stable. When they navigate the deep waters of historical legacy, old and young professionals' reasoning actually becomes muddled. This is because there is a lot of back and forth maneuvering as the groups struggle for power in the field and they use arguments strategically. As a result, both the young and the old may find themselves occasionally the opposite view from what they commonly represent.

Position-takings are thus attacked on their own grounds as the two groups maneuver to narrate the past and define the present. When the elders are discounting the knowledge of the young and simultaneously recounting their own merits that date back to socialist times, they talk about the importance of professionalism (or often specifically creativity), abandoning for a moment their stance on understanding the client. In a trade journal interview, an older CEO warns against discounting the socialist expertise and thereby mixes the dependent and autonomous principles:

Although at the time the battle among the clients wasn't as fierce, in fact, not even among the few agencies that existed, but I never for a moment felt that it's just a game. We set ourselves to a task with the highest expertise you could reach at that time, and with true professional fanaticism. That's why I wouldn't disrespect those times. Maybe the brands weren't as dependent on advertising, but the stakes were just as high for us. (Hermann and Márk 2001, my italics)

Here the speaker acknowledges the difference between a capitalist market and a socialist economy on several levels, by mentioning competitive pressure and the necessity of advertising in markets. Yet the professional argues that market conditions are not what force quality. Rather it is adherence to an internal, professional standard that drives people - departing from the stance of client-driven market-based service.

The elders assert superiority by pushing the above argument further to say that they were more competent in advertising already under socialism than the young are in capitalism. An older kreativ mourns the past successes of Hungarian advertising:

Hungarian advertising had a prosperous period that is unheard of, when there was nothing similar anywhere in Eastern Europe. That is also probably an accident because those kinds of people came together here.... This country won awards at Cannes in the 1970s, 1980s.

\footnotetext{
52 Obviously their younger counterparts think that the resignation and takeover are long overdue.
} 
Here the kreativ is implicitly glorifying the "Great Generation" of her time-how they "came to be called," according to another older colleague. To drive the point further, older creatives say they notice dullness in the industry recently, and even a "culture of mediocrity" that is built into the thinking of current advertising workers. The "fanaticism" of their own young days is again invoked, now in complaint of current ad workers' lameness. Thus, the young do not even measure up to their own standards. That is, they whine about creativity being fettered, but they simply are not creative enough. Interestingly, this criticism runs into a problem when elders cast themselves as educators of newer generations. Indeed, the kreativ cited earlier ends up admitting to their own role in the poor result:

I feel responsibility in this. Everyone who is a mester has to feel the responsibility in that it is unbelievable how there is no fanaticism, how the profession is full of what we call "creatives who just want to earn a living" (megélhetési kreativ), who are having an $\mathrm{OK}$ time, who I am sure can write very beautifully, but who simply don't have that fire in them, that revolutionary, that cheekiness, to say that "I'm going to show you all," and people in their twenties are working as if they were 70 years old.

Turning the tables, the young attack the old on market grounds. When young educators want to discredit the old-timers, they do not only claim that the latter were less professional, but also that work done under non-market conditions does not count. So they "cross over" from their usual position of advocating professional autonomy to emphasize that the imperative of the market, market thinking is foreign to the elders, and hence their expertise is irrelevant:

There is a kind of generational change, put crudely, so there have been great changes going on for a while, absolutely. So, before the regime change there wasn't any advertising per se, so, there were ads like, there was the one Traubisoda [grape-flavored soft drink-Zs. V.], and "Shoe from the shoe store!" so there wasn't a great tradition of [advertising], [the elders] only knew that commercials are necessary, because that's what they probably saw in the western world. But it was a planned economy, so the market wasn't really determined by demand and the influencing of demand, so the function of advertising was different. (CEO of an international agency, my italics) ${ }^{53}$

This argument undermines the credibility of the elders' claims about meeting the client's expectations and living off the market. Young educators further criticize the alleged commitment of the older generation to market principles in other ways. They allude to the capacity of the MAHIR circle (the communist state's main publicity department) to function as an old-boy network in allocating business and recruiting people.

Instances when generations claim each other's declared expertise-such as the two examples above-demonstrate two things: the young are not wedded to the educator role and the elders are not wedded to the service role; and that no matter

\footnotetext{
53 The respondent is referring to the type of advertisement that propagated a product category. For example, the TV ad for shoes asked Hungarians to buy "Shoes from the shoe store" (Cipot a cipoboltból). Another television spot advertised sausage. These ads became favorite targets of socialist advertising's critics.
} 
what position an actor takes, it is always vulnerable to attack in a field structured by contradictory expectations.

Figure 1 depicts the field of Hungarian advertising around 2002-2004. The horizontal axis denotes the contradictory structuring principles of the field: autonomy from the clientele (in the form of creative and artistic work) and dependence on the clientele (in short, the market). The "educators" are located nearer the art pole of the field, the "service" advocates at the market pole. The vertical axis measures how easy it was to acquire advertising expertise, but this measure is ambivalent as the debate revolves around just what the expertise is. For "educators" advertising is a highly specific profession based on creative capacity and trendsetting, and its knowledge cannot be obtained or questioned easily by outsiders. For the service group advertising is specific up to a point, but there must be room to involve the client. To phrase it differently, advertising's specificity entails its capacity to cooperate with those it depends upon. The groups' location in the field also reflects these views.

The arrows depict the hypothesized past position and subsequent movement of the two groups. The "transitional generation" came from open social relations in the early 1990s - as we have seen above, the accessibility of the field's specific expertise was low since almost anyone with some English skills could join and learn it. ${ }^{54}$ The old group had reformed socialist advertising in the name of creativity, so they occupied a position closer to the art pole of the field. As I argued above, their shift occurred for two reasons: they became capitalist business leaders, and a more credibly western group entered the field.

Adjacent to the field of advertising are the relevant professions and areas of worksuch as marketing management and artistic film directing - that are influential as ideals and challengers. Many Hungarian art directors (job title in advertising) and TV spot directors aspire to shoot a "real" movie one day. Marketing managers, on the other hand, are the everyday clients of ad agencies, and contrast their own business knowhow with the agency's creative proposals. The field of the market importantly features the consumers on whom advertising depends.

\section{Conclusion}

From a puzzling empirical observation this article has argued for an approach to professions that makes use of theoretical insights on fields of expertise. The alignment of young and old advertising professionals according to educator and service roles is the outcome of the struggle of newcomers and incumbents to dominate the field of advertising in Hungary. The young and old ad professionals respond to each other's claims by devising justifications of their actions and denunciations of others based on their own expertise. They are engaged in back and forth maneuvering, making use of the contradictory commitments of their profession, which are creative autonomy and serving clients. The professionals'

\footnotetext{
${ }^{54}$ From our small sample of elders, completed with data from the journal Kreativ, trade or socialist political economy degrees were the standard. However, we have no first-hand data on socialist hiring practices.
} 


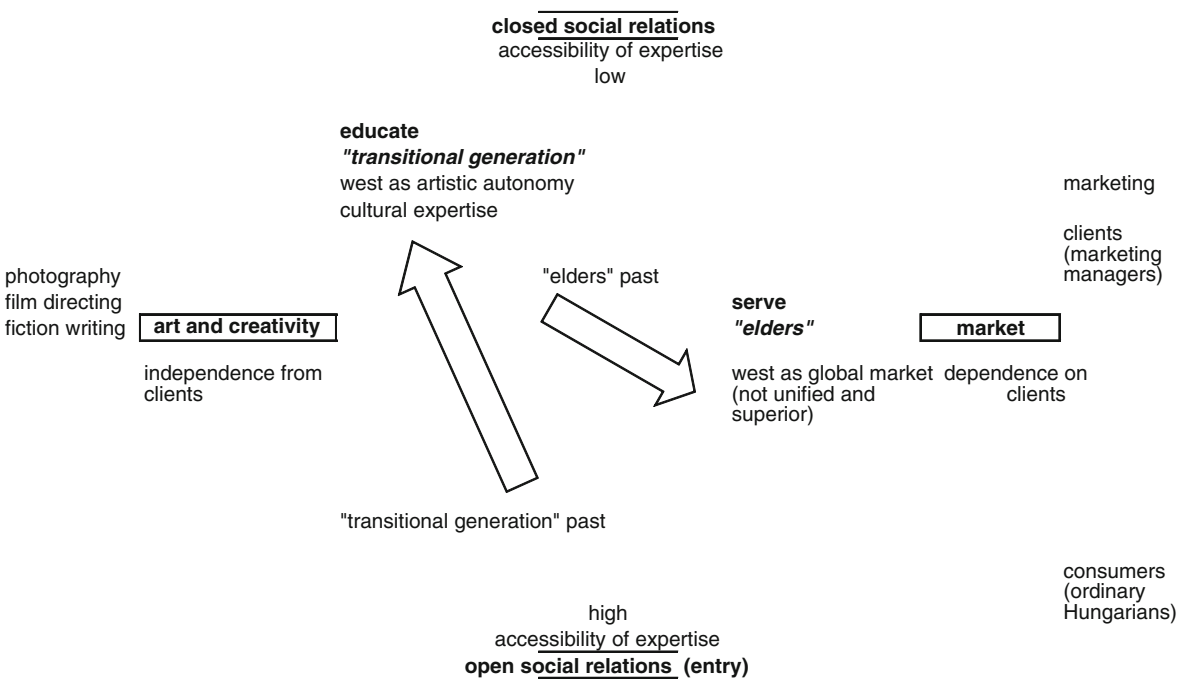

Fig. 1 The field of post-socialist Hungarian advertising

strategies - what they pick from the west and capitalism - are associated with their trajectory: their career histories developing in relation to each other. Trajectory enables and limits position-taking in the structure of available discursive positions in relation to coexistent views. What strategies actors are pursuing to wrest power from each other depends on how they entered the field and related to other groups there.

What distinguishes the Hungarian case is that actors mediate large-scale social transformation, so that struggles between new and old professionals are informed by the ongoing transformation from socialism, a project imbued with the idea of progress towards the west. Accordingly, positions that actors take about the profession are coupled with a relation to the west, either as its representative or as its critic.

The strategic position occupied by the older generation of advertising workers is to defend the socialist legacy and the virtues of the local market (their strengths) in the face of allegedly superior western practices. The "elders" are entrenched in socialism and need to demonstrate that their socialist expertise is compatible with the changed organization of their profession. So, senior professionals work on their "purification" from socialism (Eyal 2003), but they also try to salvage what is valuable from the socialist past in which they are invested. On the other hand, they also wish to demonstrate their deep engagement with, and allegiance to, capitalism. Their experience running international advertising agencies gives them the authority to argue about the importance of clients, since they had to cater to clients to survive in postsocialist times. As more recent entrants to the field, the young practitioners are disposed to be advocates of the novel-western. The "transitional generation" benefits from arguing that advertising should follow western norms because it is expert of the west by habitus. Thus they can represent the west as the locus of autonomy, and autonomy as the essence of advertising, credibly. Their strife for autonomy renders the young as heroic modernizers who must educate their audiences into the ways of the west.

These positions are not in isolation; they are responding to one another. Thus, the legitimacy of the incumbent older group is challenged by the younger rivals. 
Educators try to prove that the elders, representatives of the old regime, are behind in western matters and professionally incompetent. ${ }^{55}$ Vice versa, the elders consider the young unprofessional because those fail to identify with serving clients. The elders criticize the superiority of the west and the new knowledge because, although earlier at the forefront of post-socialist change, they are now being phased out as modernizers.

The strategizing, as the issue of post-socialist transition illustrates, also does not operate on a simple bipolar scheme, since all actors must balance the professional field's tension. They will inevitably contradict themselves and live with it. It also means that the clustering of opposing views into two main positions (new-modernwestern-young-autonomous and old-outdated-west-skeptical-service-oriented) is undermined by maneuvering actors who draw on elements of the opposite side. For this reason, young and old should not be seen simply as the respective "winners and losers of the transition" (for a similar observation see Zentai 1999).

The analysis presented here is a snapshot of a field that is constantly evolving. The older cohorts of "transitionals" are becoming the dominant group as the "elders" are being phased out. The point was to show the dynamic, the tension exploited by actors that drives positioning. Actors are engaged in providing winning definitions of their profession, framed in terms of independence or dependence on the profession's clientele. Since there is more than one principle available to measure professional status, dominant views shift and challengers keep emerging. A question for the Hungarian case is the role of the youngest entrants, who are less "transitional" than truly "post-socialist," and who may come to challenge the educators in the name of service, perhaps with the alliance of the elders. ${ }^{56}$

\footnotetext{
${ }^{55}$ As noted before, although biological age plays a part in the phenomenon studied here, age is first of all social and refers to experience and rank. As Bourdieu observes, "[s]tructurally 'young' writers, i.e., those less advanced in the process of consecration... will refuse everything their 'elders' (in terms of legitimacy) are and do, and in particular all the indices of social ageing" (Bourdieu 1993: 59). Thus the new entrants can hold up the west against the achievements of Hungarian advertising and thereby implicitly question the authority of their old "masters."

${ }^{56}$ The youngest ad professionals my come to identify with "profession as service" as they develop a strategy to gain power in light of the other groups' positions. This is another example of why trajectory is a relational concept: we cannot predict what will happen based only on the youngest ad professionals' careers. We could either assert that the youngest cohorts' career and experience is different from the "transitional" cohorts and hypothesize that their relative newcomer status will put them in opposition with the older transitional group - so the youngest will side with the elders and represent profession as service. A question is why aren't they doing it already? The second hypothesis is to claim that the careers of transitional cohorts are altogether similar and any difference is only a matter of degree. Then, as Hungarian advertising sets up higher barriers to entry, we expect that the youngest ad professionals will represent advertising's creative autonomy. But they currently do not. Finally, we cannot assume that the generational divide remains the relevant one within a post-socialist space. It may well be that the youngest cohort will be divided over what advertising should do based on yet other characteristics, such as gender or the conventional organizational boundaries - that question is beyond the scope of this article. Evidence of opening towards the elders and continuity is that the youngest advertising workers who are in their twenties hail Hungarian advertising's "glorious days" in the 1970s, much more frequently than colleagues in their thirties. The youngest also tend to be more enthusiastic about the old mesterek and to claim without reserve that many socialist ads were extremely good. The youngest advertising workers are sufficiently far from the experience of socialism and close to the experience of the west, to safely embrace some elements of socialism, as a kind of Ostalgie (the German term for nostalgia for socialist East Germany). At the same time, several elders seemed to be keen on working with youngsters, both to train them into their craft, and to gauge contemporary youth culture.
} 
My approach to professions attempts to break with the idea that the primary driving force of a profession is control over expertise and the strife for autonomy and power. The concept of cultural intermediaries, the other relevant tool to analyze advertising, is based on a similar asymmetry: the presumption that experts convey knowledge about consumption downwards to society through a brokerage position between the dominant classes and the masses. But I argue that cultural intermediaries have their own internal movements, where the claim not to broker, or to broker upward can be just as successful as the claim to the mission of dispersing knowledge to the uninitiated.

This paper built on findings about advertising from the "production of culture" perspective, and contributes a new aspect to that line of research. The approach, as developed by Richard Peterson (1976), has been interested in showing the relationship between the conditions of producing cultural goods and the latter's various properties (quality, diversity, accessibility, style, market categorization). The research on Hungarian advertising professionals adds an illustration of how producers reflect on their product, how they identify with it or alienate it from themselves as a consequence of the circumstances of production: the advertising agency's relationship to clients and the general public. Essentially, both the "educator" and the "service" positions are accounts of why Hungarian ads are poor. From this perspective it is difficult to establish whether educators and the service friendly make different ads, precisely because position-taking as educator does not mean that one actually gets to do ads more independently. Ad-making is collaborative work (Becker 1982) and adherents of both professional principles are found in most major agencies. Rather, advertisements are read by the two groups with opposite hypotheses about behind-the-façade relations of production. For example, for award-winning ads one can tell a story of creative boldness or of fruitful agency-client cooperation. ${ }^{57}$

In a way, this article advances Andrew Abbott's theory of purification (Abbott 1981, 1988). It makes the case that while purity, the single ordering principle of professional status according to Abbott, is a powerful means of justification, it is constantly challenged. Efforts to purify the world from hybrids only lead to their proliferation (Latour 1993). Although advertising may be more heteronomous or hybrid than the "classical" professions, that only makes it a clearer illustration of the general point. All professional fields are hybrids of the economic and some specific expertise, but while some of its participants are working to purify it, others will muddle it even more. Thus, the outcome of the fight for status ordering may vary from case to case.

Acknowledgments The author would like to thank Gil Eyal, Peter Bearman, David Stark, Virág Molnár, Martin Ruef, Bradley Abrams, Nancy Davenport, Dan Lainer-Vos, and the anonymous reviewers and

\footnotetext{
${ }^{57}$ But the debate is not a mere opposition between idealists (who chase unattainable dreams about professional autonomy) and realists (who are saying that in reality there are market constraints). Seeing it in these terms would be coming down on the side of service. Instead of calling each other idealist or cynical, the term that is meaningful for actors is "unprofessional." Both groups have adjusted their worldview to their respective situation in the advertising field, so that the "space of possibles" is different: the service group really believes that it isn't ideal to have the kind of "self-serving" ads that educators worship, while the latter really believe they are on a mission to improve business and society.
} 
Editors of Theory and Society for their helpful comments on earlier drafts of this article. Part of this research was funded by the Hungarian National Science Foundation (OTKA) grant no. T38418, and by the PepsiCo Fellowship for Travel/Research in the former Soviet Union and East Central Europe, awarded by the Harriman Institute at Columbia University.

Open Access This article is distributed under the terms of the Creative Commons Attribution Noncommercial License which permits any noncommercial use, distribution, and reproduction in any medium, provided the original author(s) and source are credited.

\section{References}

(2004). Nagy Kreativ Könyv. (Great Creative Book) (Budapest: Geomédia Kiadó)

Abbott, A. D. (1981). Status and status strain in the professions. American Journal of Sociology, 86(4), 819-835.

Abbott, A. D. (1988). The system of professions: An essay on the division of expert labor. Chicago: University of Chicago Press.

Abrams, B. (2007). Reklama or Propagace? The rise and fall of socialist advertising: A bellwether of Normalization. In: Normalizing the socialist good life: Consumption, consumerism and political legitimacy in Czechoslovakia after the Prague Spring. New York

Bandelj, N., \& Purg, D. (2006). Networks as resources, organizational logic, and change mechanism: the case of private business schools in post-socialism. Sociological Forum, 21(4), 587-622.

Becker, H. S. (1982). Art worlds. Berkeley: University of California Press.

Bockman, J., \& Eyal, G. (2002). Eastern Europe as a laboratory for economic knowledge: the transnational roots of neoliberalism. American Journal of Sociology, 108(2), 310-352.

Böröcz, J., \& Róna-Tas, Á. (1995). Small leap forward: emergence of new economic elites. Theory and Society, 24 (5 Special Issue on Circulation vs. Reproduction of Elites during the Postcommunist Transformation of Eastern Europe (October)), 751-781

Bourdieu, P. (1984). Distinction: A social critique of the judgement of taste. Cambridge: Harvard University Press.

Bourdieu, P. (1993). The field of cultural production: Essays on art and literature. New York: Columbia University Press.

Boyer, D. (2006). Gender and the solvency of professionalism: Eastern German journalism before and after 1989. East European Politics and Societies, 20(1), 152-179.

Cook, D. T. (2007). In pursuit of the 'inside view': training the research gaze on advertising and market practitioners. In R. W. Belk (Ed.), Handbook of qualitative research methods in marketing. Cheltenham: Elgar.

Cronin, A. M. (2003, November). "Regimes of mediation: advertising practitioners as cultural intermediaries?" Retrieved April 20, 2005, from www.comp.lancs.ac.uk/sociology/papers/CroninRegimes-of-Mediation.pdf

Dávila, A. M. (2001). Latinos, Inc.: The marketing and making of a people. Berkeley: University of California Press.

De Grazia, V. (2005). Irresistible empire: America's advance through twentieth-century Europe. Cambridge: Belknap Press of Harvard University Press.

Dessewffy, T. (2002). Speculators and travellers: the political construction of the tourist in the Kadar regime. Cultural Studies, 26(1), 44-62.

DiMaggio, P. J., \& Powell, W. W. (1983). The iron cage revisited: institutional isomorphism and collective rationality in organizational fields. American Sociological Review, 48(2), 147-160.

Drazen, J. M., \& Epstein, A. M. (2002). Rethinking medical training: the critical work ahead. New England Journal of Medicine, 347, 1271-1272.

Dunn, E. C. (2004). Privatizing Poland: Baby food, big business, and the remaking of labor. Ithaca: Cornell University Press.

Effie. (2007). Retrieved August 27, 2007, from www.effie.org

Evetts, J. (2005, July). Organizational and Occupational Professionalism: The Challenge of Public Management. Paper presented at the Frontiers of Sociology: 37th World Congress of the International Institute of Sociology, Stockholm, Sweden.

Eyal, G. (2000). Anti-politics and the spirit of capitalism: dissidents, monetarists, and the Czech transition to capitalism. Theory and Society, 29(1), 49-92. 
Eyal, G. (2002). Dangerous liaisons between military intelligence and Middle Eastern studies in Israel. Theory and Society, 31(5), 653-693.

Eyal, G. (2003). The origins of postcommunist elites: From Prague Spring to the breakup of Czechoslovakia. Minneapolis: University of Minnesota Press.

Eyal, G., Szelényi, I., \& Townsley, E. R. (1998). Making capitalism without capitalists: Class formation and elite struggles in post-communist Central Europe. London: Verso.

Faraday, G. (2000). Revolt of the filmmakers: The struggle for artistic autonomy and the fall of the Soviet film industry. University Park: Pennsylvania State University Press.

Featherstone, M. (1991). Consumer culture and postmodernism. London: Sage.

Fox, S. R. (1984). The mirror makers: A history of American advertising and its creators. New York: Morrow. Freidson, E. (1984). The changing nature of professional control. Annual Review of Sociology, 10, 1-20. Garofalo, R. (1992). Rockin' the boat: Mass music and mass movements. Boston: South End Press.

Gayer, Z. (1998). Fényképaktusok: amatőrképek a rendszerváltás előtt és után. (Photo acts: amateur photographs before and after the transition). Replika, 33-34, 87-102.

Gecser, O., \& Kitzinger, D. (2002). Fairy Sales: the Budapest international fairs as virtual shopping tours. Cultural Studies, 26(1), 145-164.

Gitlin, T. (2000). Inside prime time. Berkeley: University of California Press.

Grabher, G. (2001). Ecologies of creativity: the village, the group, and the heterarchic organisation of the British advertising agency. Environment and Planning A, 33(2), 351-374.

Gronow, J. (2003). Caviar with champagne: Common luxury and the ideals of the good life in Stalin's Russia. Oxford: Berg.

Guillen, M. (1997). Scientific management's lost aesthetic: architecture, organization, and the taylorized beauty of the mechanical. Administrative Science Quarterly, 42, 682-715.

Hammer, F. (2002). A gasoline scented Sindbad: the truck driver as a popular hero in socialist Hungary. Cultural Studies, 16(1), 80-126.

Hammer, F., \& Dessewffy, T. (1997). A fogyasztás kísértete. (The Specter of Consumption). Replika, 26, $31-46$.

Hennion, A., Meadel, C., \& Bowker, G. (1989). The artisans of desire: the mediation of advertising between product and consumer. Sociological Theory, 7(2), 191-209.

Hermann, I. (2001a). "Hallgatnak ránk: Interjú Megyer Örssel, az Önszabályozó Reklámtestület elnökével." (They listen to us: Interview with Ors Megyer, president of the Self-Regulatory Body of Advertising) Retrieved April 20, 2005, from www.kreativ.hu.

Hermann, I. (2001b). "Sárguló történetek: Interjú Csepregi Miklóssal, az Ogilvy vezetőjével." (Yellowing stories: Interview with Miklós Csepregi, leader of Ogilvy) Retrieved April 20, 2005, from www.kreativ.hu.

Hermann, I., \& Márk, S. (2001). Rég volt, szép volt: Interjú a Lowe Lintas GGK vezetőségével (Good Old Times: Interview with the management of Lowe Lintas GGK). Kreativ Magazin, Volume X. Issue 20. October 31, 2001. www.kreativ.hu. Accessed on July 20, 2006.

Hesmondhalgh, D. (2002). The cultural industries. London: Sage.

Hogg, M., \& Scoggins, B. (2001). Telling tales: An ethnographic account of creativity in agency-client relations. Conference paper. Critical Management Studies Conference. Manchester, UK. July 2001.

Iglehart, J. K. (2008). Revisiting duty-hour limits: IOM recommendations for patient safety and resident education. New England Journal of Medicine, 359, 2633-2635.

Kennedy, M. D. (2002). Cultural formations of postcommunism: Emancipation, transition, nation, and war. Minneapolis: University of Minnesota Press.

Kreatív. (2000). A Mahírtől a multikig. (From MAHIR to the multi's). Kreativ Magazin, Volume IX. Issue 3, March 23, 2000. www.kreativ.hu. Accessed on July 21, 2006.

Larson, M. S. (1977). The rise of professionalism: A sociological analysis. Berkeley: University of California Press.

Larson, M. S. (1993). Behind the postmodern facade: Architectural change in late twentieth-century America. Berkeley: University of California Press.

Larson, J. (2002). Selling oneself, selling the nation: Translating Slovaks for the eyes of Europe. Anthropology of East Europe Review, 20 (2 Special Issue: New Directions in Post-Socialist Studies). Accessed online on September 7, $2007 \mathrm{http} / / /$ condor.depaul.edu/ rrotenbe/aeer/v20n2/Larson.pdf.

Lash, S. (1990). Sociology of postmodernism. London: Routledge.

Latour, B. (1993). We have never been modern. New York: Harvester Wheatsheaf.

Lears, T. J. J. (1987). Uneasy courtship: modern art and modern advertising. American Quarterly, 39(1), 133-154.

Magyar Reklámszövetség (Hungarian Advertising Association). (2008). www.mrsz.hu Accessed November 25, 2008. 
Marchand, R. (1985). Advertising the American dream: Making way for modernity, 1920-1940. Berkeley: University of California Press.

Mayer, M. (1958). Madison Avenue, USA. New York: Harper.

Mazzarella, W. (2003). Shoveling smoke: Advertising and globalization in contemporary India. Durham: Duke University Press.

McFall, E. R. (2004). Advertising: A cultural economy. London: Sage.

Melegh, A. (2003). A kelet/nyugat lejtő. (The east/west slope). Élet és Irodalom, 47, 17,

Moeran, B. (2003). Fields, networks and frames: advertising social organization in Japan. Global Networks, 3(3), 371-386.

Molnár, V. (2005). Cultural politics and modernist architecture: the tulip debate in postwar Hungary. American Sociological Review, 70(1), 111-135.

Mort, F. (1996). Cultures of consumption: Masculinities and social space in late twentieth-century Britain. London: Routledge.

Nike. (2004). "Nike Brazil vs. Portugal Ad 2004." Retrieved September 11, 2007, from http://www. metacafe.com/watch/31628/nike_football_brazil_vs_portugal/.

Nixon, S. (1996). Hard looks: Masculinities, spectatorship and contemporary consumption. London: UCL Press.

Parikh, S. (2001). Professionalism and its discontents: A study of social networks in the plaintiff's personal injury bar. Dissertation: University of Illinois.

Patterson, P. H. (2003). Truth half told: finding the perfect pitch for advertising and marketing in socialist Yugoslavia, 1950-1991. Enterprise Soc, 4(2), 179-225.

Patterson, P. (2004, June). Advertising in socialist Eastern Europe. Paper presented at History Department, Central European University, Budapest, Hungary.

Peterson, R. A. (1976). The production of culture: a prolegomenon. American Behavioral Scientist, 19(6), 669-684.

Peterson, R. A., \& Anand, N. (2004). The production of culture perspective. Annual Review of Sociology, 30(1), 311-334.

Reid, S. (2000). Style and socialism: Modernity and material culture in post-war Eastern Europe. Oxford: Berg.

Rona-Tas, A. (1997). The great surprise of the small transformation: The demise of communism and the rise of the private sector in Hungary. Ann Arbor: The University of Michigan Press.

Salganik M. J., Dodds P. S., \& Watts D. J. (2006). Experimental study of inequality and unpredictability in an artificial cultural market. Science, 311, 854-856.

Schudson, M. (1984). Advertising, the uneasy persuasion: Its dubious impact on American society. New York: Basic Books.

Soar, M. (2000). Encoding advertisements: ideology and meaning in advertising production. Mass Communications \& Society, 3(4), 415-437.

Stark, D. (1996). Recombinant property in East European capitalism. American Journal of Sociology, 101 (4), 993-1027.

Stark, D., \& Bruszt, L. (2001). One way or multiple paths: for a comparative sociology of East European capitalism. American Journal of Sociology, 106(4), 1129-1137.

Stark, D., Bruszt, L., \& Vedres, B. (2006). Rooted transnational publics: integrating foreign ties and civic activism. Theory and Society, 35(3), 323-349.

Stoilkova, M. (2004) Exiles at Home and Abroad: Bulgarian Intelligentsia in Emigration. Dissertation, University of California Berkeley.

Szelényi, I., \& King, L. P. (2005). Post-communist economic systems. In N. J. Smelser \& R. Swedberg (Eds.), The handbook of economic sociology. Princeton: Princeton University Press; Russell Sage Foundation.

Thornton, S. (1999). An academic Alice in Adland: ethnography and the commercial world. Critical Quarterly, 41(1), 58-68.

Todorova, M. N. (1997). Imagining the Balkans. New York: Oxford University Press.

Tunstall, J. (1964). The advertising man in London advertising agencies. London: Chapman \& Hall.

Vörös, M. (1996). Életmód, ideológia, háztartás. A fogyasztáskutatás politikuma az államszocializmus korszakában. (Way of life, ideology, household: the politics of consumption research in the state socialist period). Replika, 26, 17-30.

Wachter, R. M. (2008). Understanding patient safety. New York: McGraw-Hill Medical.

Weiner, E. (2007). Market dreams: Gender, class, and capitalism in the Czech Republic. Ann Arbor: University of Michigan Press.

Wessely, A. (2002). Travelling people, travelling objects. Cultural Studies, 16(1), 3-15.

Wolff, L. (1994). Inventing Eastern Europe: The map of civilization on the mind of the Enlightenment. Stanford: Stanford University Press. 
Yurchak, A. (2003). Russian Neoliberal: The Entrepreneurial Ethic and the Spirit of New Careerism. Russian Review, 62.

Yurchak, A. (2006). Everything was forever, until it was no more: The last Soviet generation. Princeton: Princeton University Press.

Zentai, V. (1999). From losers and winners to victims and perpetrators. IWM Working Papers (Working paper No. 5: Vienna).

Zsuzsanna Vargha is a Postdoctoral Research Fellow at the Max Planck Institute for the Study of Societies, receiving her Ph.D. in Sociology at Columbia University. Her dissertation, entitled "Technologies of Persuasion: Personal Selling and the Making of Markets in Consumer Finance," is a study of the interactional foundations of exchange. Currently she is working on the new non-institutional forms of lending. 